\title{
"Testing performance of an interest rate commission agent banking system
}

(AIRCABS)"

\begin{tabular}{|c|c|c|}
\hline AUTHORS & \multicolumn{2}{|l|}{$\begin{array}{l}\text { Ameha Tefera Tessema } \\
\text { Jan Walters Kruger }\end{array}$} \\
\hline ARTICLE INFO & \multicolumn{2}{|c|}{$\begin{array}{l}\text { Ameha Tefera Tessema and Jan Walters Kruger (2017). Testing performance of } \\
\text { an interest rate commission agent banking system (AIRCABS). Banks and Bank } \\
\text { Systems, 12(3), 113-141. doi:10.21511/bbs.12(3).2017.09 }\end{array}$} \\
\hline DOI & \multicolumn{2}{|c|}{ http://dx.doi.org/10.21511/bbs.12(3).2017.09 } \\
\hline RELEASED ON & \multicolumn{2}{|l|}{ Thursday, 07 September 2017} \\
\hline RECEIVED ON & \multicolumn{2}{|l|}{ Wednesday, 24 May 2017} \\
\hline ACCEPTED ON & \multicolumn{2}{|l|}{ Wednesday, 14 June 2017} \\
\hline & \multicolumn{2}{|l|}{\begin{tabular}{|l|l|}
$(c))_{\text {EY-NC }}$ \\
\end{tabular}} \\
\hline LICENSE & \multicolumn{2}{|c|}{$\begin{array}{l}\text { This work is licensed under a Creative Commons Attribution-NonCommercial } 4.0 \\
\text { International License }\end{array}$} \\
\hline JOURNAL & \multicolumn{2}{|l|}{ "Banks and Bank Systems" } \\
\hline ISSN PRINT & \multicolumn{2}{|l|}{$1816-7403$} \\
\hline ISSN ONLINE & \multicolumn{2}{|l|}{$1991-7074$} \\
\hline PUBLISHER & \multicolumn{2}{|c|}{ LLC "Consulting Publishing Company "Business Perspectives" } \\
\hline FOUNDER & \multicolumn{2}{|c|}{ LLC "Consulting Publishing Company "Business Perspectives" } \\
\hline  & & 三云: \\
\hline NUMBER OF REFERENCES & NUMBER OF FIGURES & NUMBER OF TABLES \\
\hline 44 & 1 & 33 \\
\hline
\end{tabular}

(c) The author(s) 2021. This publication is an open access article. 


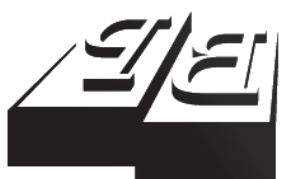

BUSINESS PERSPECTIVES

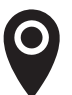

LLC "CPC "Business Perspectives" Hryhorii Skovoroda lane, 10, Sumy, 40022, Ukraine

www.businessperspectives.org

Received on: $24^{\text {th }}$ of May, 2017 Accepted on: $14^{\text {th }}$ of June, 2017

(c) Ameha Tefera Tessema, Jan Walters Kruger, 2017

Ameha Tefera Tessema, Doctor of Business Leadership, School of Business Leadership, University of South Africa, South Africa.

Jan Walters Kruger, Professor of Corporate Finance, School of Business Leadership, University of South Africa, South Africa.

\section{(ㄷ)(1) $(8$}

This is an Open Access article, distributed under the terms of the Creative Commons Attribution-NonCommercial 4.0 International license, which permits re-use, distribution, and reproduction, provided the materials aren't used for commercial purposes and the original work is properly cited.

\title{
TESTING PERFORMANCE OF AN INTEREST RATE COMMISSION AGENT BANKING SYSTEM (AIRCABS)
}

\begin{abstract}
This paper sought to analyze data and interpret statistical results in testing the performance of an interest rate commission agent banking system. Primary and secondary data were collected from banking industry in Ethiopia to test the research hypotheses, credit risk and liquidity crunch have no impact on AIRCABS, investor loan funding has a positive impact on profitability and sustainability of AIRCABS and discrete market deposit interest rate incentive has a positive impact on stable deposit mobilization in a bank. To test the hypothesis, statistical tools such as Cronbach's alpha, KuderRichardson (KR-20), canonical correlation and multinomial logistic regression were used. The result showed that credit risk and liquidity crunch have no effect on an interest rate commission agent banking system, investor loan funding has a significant strong relationship with profitability and sustainability of AIRCABS and discrete market deposit interest rate incentive has also a significant strong relationship with stable deposit mobilization. This led to a conclusion that an interest rate commission agent banking system (AIRCABS) model is viable and reliable.
\end{abstract}

Keywords

\section{JEL Classification}

\section{INTRODUCTION}

Disbursing loan holding customer deposit as an asset has exposed the banking business to credit risks and liquidity crunch. To solve banking crises which arose from credit risk and liquidity crunch, business models adopted by banks were a catalyst for financial crisis (Blommestein, Keskinler, \& Lucas, 2011; Zuckerman, 2011; Baicu \& State, 2012; Bruno \& Bedendo, 2013; Mandel, Morgan, \& Wei, 2012; Young, McCord, \& Crowford, 2010). Because bank runs its business either retaining or transferring credit and liquidity risks to other financial institutions, which later has the same impact on the overall industry.

Transferring credit and liquidity risks to entrepreneurs and investors enables the bank to maintain its sustainability and profitability in the market. This can be done by empowering money depositors to exercise their full right for the use of their money to get reasonable credit price rather than offering an unreasonable deposit interest rate that forced them to join the informal market (Simon-oak \& Jolaosho, 2013). Transferring credit risk using financial instruments such as derivatives caused to aggravated financial crisis (Gogoncea \& Paun, 2013). The main reason behind this fact is banks are disbursing loan considering customers' deposit as their own asset on their balance sheet. 
To maintain the mutual benefit of investor, entrepreneur and the bank, an interest rate commission agent banking system was developed (Tessema \& Kruger, 2016). An interest rate commission agent banking system is defined as a system adopted by the bank to be an agent for investors loan funding to entrepreneurs getting the fund seller and buyer agreement to administer the loan after disbursement by retaining reasonable interest rate commission from agreed investors' loan funding credit price (Tessema \& Kruger, 2016). Since the agent bank doesn't hold customer deposits as an asset, it is exempted from expensing deposit interest. As a matter of fact, the agent banks collect interest commission from investor loan funding administration without credit and liquidity risks higher than the interest rate margin collected by the traditional banking system. Whilst investor and entrepreneurs present to process loan transaction at the agent bank, the selected agent bank assesses the entrepreneur's project in accordance with the central bank rules and regulation. After the agent bank made them sign a tripartite loan contract agreement between investor, entrepreneur and also the agent bank itself, investor and entrepreneur opened a special deposit account by which the loan transaction from an investor account to entrepreneur account has taken place. The agent bank administers the loan after disbursement by maintaining off balance sheet account for the loan accounting record. While the entrepreneur periodically repays the portion of interest and principal, the agent bank transfers the repayment into investor account excising agreed interest rate commission, which stated in the loan contract. So the investor has an opportunity to collect the money sold to entrepreneur, duly or in lump sums per the agreement. Since the investor collects its benefit throughout the loan period without waiting till the bank accounting period where its profit and loss disclosed, this enables an investor to mitigate risks related to credit and liquidity. The agent bank also mitigates investor and entrepreneurs' risks related to credit and liquidity by maintaining operational efficiency through enhanced human capital efficiency, structural capital efficiency and capital employed efficiency (Tessema \& Kruger, 2016).

\section{CREDIT AND LIQUIDITY RISK TRANSFER MECHANISM OF AN INTEREST RATE COMMISSION AGENT BANKING SYSTEM}

An interest rate commission agent banking system (AIRCABS) maximizes profitability, sustainability, operational efficiency, liquidity and capital by transferring credit risk and liquidity crunch to investors and entrepreneurs. Being an interest commission agent banking system needs to be more efficient in technology, human capital and finance, and applying inadequate technology and human capital most likely exposes the agent bank to operational risk (Tessema \& Kruger, 2016).

In modern banking system, risk can be transferred either by selling the loan or buying insurance through credit default swap. In bank credit risk transferring, insurance company plays a big role giving insurance coverage for loans under the administration of a bank. So under conventional banking, transferring credit risk can only improve risk diversification if the risk transfer is between bank and insurance sectors. However, transferring credit risk can bring contagion effect on the institutions where the transaction was carried out which can in turn increases the systematic risk which makes market participants financially damaged, in particulars, and later has an impact on the economy as a whole (Allen \& Carletti, 2006).

Since the credit risk depended on the borrower's internal and external factors such as failure to administer bank loan, commodity price and market price inflation before getting started the business, credit risk is not entirely manageable in the conventional banking system. However, credit risk and liquidity crunch which caused the banking business to prone were managed by an interest rate commission agent banking system, which transfers credit and liquidity risks to entrepreneurs and investors rendering service selling to get an interest rate commission and fees.

An interest rate commission agent banking system which shall be adopted by the bank needs to develop three lending strategies: 360 degrees, 180 degrees and 90 degree (Tessema \& Kruger, 2016): 


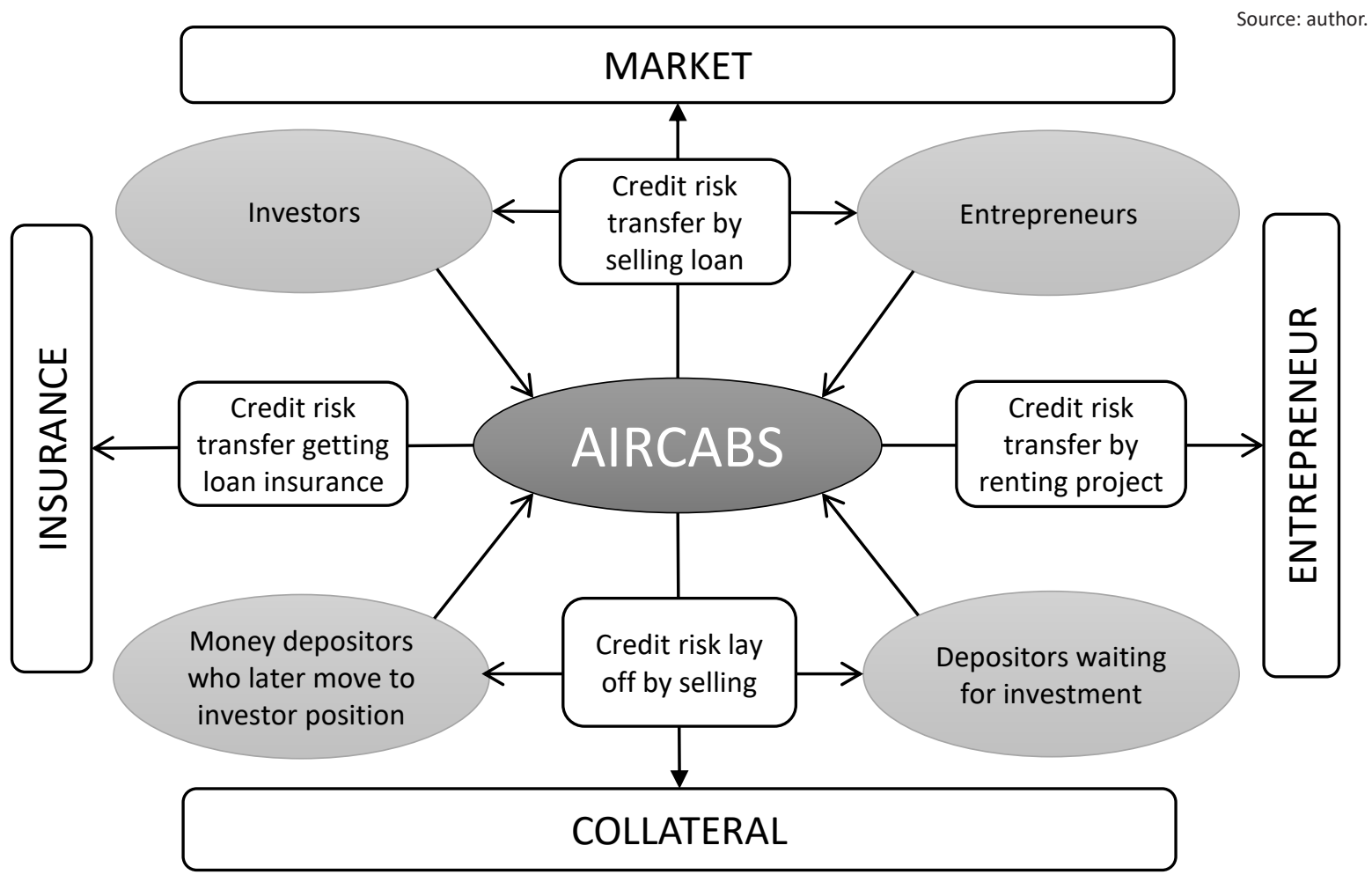

Figure 1. AIRCABS risk transfer mechanism

- 360-degree lending strategy: involves investor and entrepreneur who know to each other and an agent bank. Investor and entrepreneur are presented at agent bank at the same point in time. An investor can fund loans to entrepreneur by selecting the entrepreneur's project through an interest rate commission agent bank with or without pledging entrepreneur's collateral.

- 180-degree lending strategy: involves investor and entrepreneur who do not know each other and an agent bank. Investor and entrepreneur are presented at different point in time at the agent bank. By this lending strategy, an interest rate commission agent bank selects entrepreneur's project to be financed by an investor having pledged entrepreneur's collateral. In selecting the entrepreneur's project, the bank charges investor project selection fee.

- 90-degree lending strategy: involves the fund provider and the bank. By this lending strategy, the fund provider is money depositor who later shifts full or partial fund for investment to fund the entrepreneur's project through an agent bank to collect partial or full credit price through the loan period. Otherwise the investor sells fund to the bank to collect discrete market deposit interest incentive according to the deposit increment level.

The lending strategies were developed designed to shift credit risk and liquidity crunch to investor and entrepreneurs and thereby maximize the agent bank's profitability and sustainability in the market. Transferring credit risk to nonbank parties enables to enhance more stable financial sector than transferring credit risk within the banking sector (Wagner \& Marsh, 2006). While the investor provides loan funding to entrepreneur, the agent bank (AIRCAB) doesn't hold disbursed funds as an asset and ceases paying deposit interest expense on the fund disbursed amount.

As has depicted in Figure 1, an interest rate commission agent banking system was designed to transfer credit risk and liquidity crunch to investors and entrepreneurs to maximize profitability and sustainability in the market. In 360 degree 
lending strategy, investor and entrepreneur know each other and pledging collateral by the entrepreneur to an investor is optional. However, if the entrepreneur failed to pay debt obligation, the agent bank (AIRCABS) of an investor searches an entrepreneur that has the same project interest and rents the project till the loan has settled without ownership transfer, which can be made by ultimate decision of an investor and the agent bank. Because of some internal and external factors, an investor that has already invested in an entrepreneurial project may want to withdraw between the loan periods. In this case, the agent bank sells the project to a new investor who has the same project interest in the market refunding former investor the balance to date of sales carried out. The agent bank administers loan disbursed to an entrepreneur till the loan is settled by collecting interest rate commission and additional service fee from investors by transferring the credit risk to new investors and entrepreneurs.

Investors who have sufficient fund and wish to invest funds in alternative investment projects get an advice from the agent bank how to place their fund into investment. In this case, in 180 degree lending strategy, the agent bank can select a feasible project from those entrepreneurs who applied for funding at the agent bank earlier or can select from market to meet the investor's interest. Since investor and entrepreneur had no early acquaintance, pledging collateral by the entrepreneur is mandatory. The collateral may be the project under investment or an asset that gives service during the application period. The pledged collateral against the loan disbursed from an investor's account should have a safe margin rate between $91 \%$ and $100 \%$ to get a $90 \%$ loan on the collateral value unless an entrepreneur covers the remaining more than or equal to $10 \%$ safe margin by buying insurance from an insurance company. The insurance company may recover the default amount beyond the original loan balance or according to the agreement between the entrepreneur and the insurance company. Here the agent bank may not advise the entrepreneur to buy insurance for loan repayment coverage rather it manages the loan to get paid in due time specified in the loan contract. Otherwise, if an entrepreneur failed to pay the debt obligation above $100 \%$ of the collateral value, the agent bank would auction the collateral together with the project under investment and obliged to collect the fund disbursed together with the interest accrued to reimburse the remaining unpaid balance to investor and its uncollected interest rate commission and additional administrative expenses. The agent bank sells the pledged collateral when no alternative investment solution could be found. However, the main target of the agent bank is to benefit the investor and the entrepreneur by mitigating the risk related with the business running by entrepreneurs. As a matter of fact, the agent bank rented the project of entrepreneur for new entrepreneur that has the same project interest till the loan is settled holding the collateral and without ownership transfer. Here the benefit of the new entrepreneur has that the business runs with the support of entrepreneur's own fund without paying house rent with full-fledged facility and collect business profit beyond loan repayment mad to investor. Here the agent bank transfers the credit risk of an investor and an entrepreneur to new entrepreneur.

In 90 degree lending strategy, the depositor who wished to be an investor in the deposit periods has consulted the bank that had already invested the depositor's fund in a selective project earlier. The bank which consulted by the depositor shifts to agent position after having a formal agreement between the new investor and the agent bank for the portion of funds invested. The agent bank ceases calculating deposit interest into a deposit account of new investor to benefit proportional credit price according to proportional fund considered in the total fund that was already disbursed by the bank to the debtor earlier and thereby collected proportional interest rate commission from the investor credit price. This can be done if an interest rate commission agent banking system is a unit of a bank which already runs under the conventional banking system. The loan already disbursed to a debtor has insurance coverage and pledged collateral against the loan. So while the depositor moves later to investor position in the deposit period, the credit risk of an investor transfers to on the fate of pledged collateral and insurance engaged by an entrepreneur.

So an interest rate commission agent bank can transfer credit risk by selling loans to new investors, renting the project to new entrepreneurs, selling collateral and getting loan repayment insurance coverage. 
Since the agent bank does not hold the customer deposit as an asset on its balance sheet, it is not affected by market and credit risks. Furthermore, the agent bank is equipped with high cutting age risk predictor employees who devoted their ultimate capacity to lay off credit risk of investors and entrepreneurs.

\section{PROBLEM STATEMENT}

A business model adopted by banks made them either retain risk or transfer risk to other financial institutions, which later led to have the same effect on the industry. Because of this fact, financial crisis emanated from credit risk and liquidity crunch resulted in bank failure has not yet solved (Moise \& Ilie, 2012; Adrian, 2015; Memmel, Sachs, \& Stein, 2012). To solve these problems, an interest rate commission agent banking business model that transfers credit and liquidity risks to investors and entrepreneurs by increasing the agent bank's sustainability, profitability and stable deposit was not yet empirically tested to explore the model viability and reliability (Tessema \& Kruger, 2016).

\subsection{Research hypotheses}

The research study aims to investigate and analyze the relationship between independent and dependent variables of the following research hypotheses:

H0: credit risk and liquidity crunch have no positive effect on an interest rate commission agent banking system;

H1: investor loan funding has a positive effect on profitability and sustainability of an interest rate commission agent banking system;

H2: discrete market deposit interest rate incentive has a positive effect on stable deposit mobilization in the bank.

\section{MATERIAL AND METHODS}

The research study follows positivist data collection methods which help to test the hypotheses based on primary and secondary data.
Primary data were collected using self-administered and structured survey questionnaires from 300 commercial banks' employees among 1000population of banks, which are found in Addis Ababa, Ethiopia. The reliability and validity of survey questionnaires tested using Cronbach alpha for Likert scale and KuderRichardson(KR-20) for binary scale and analyzed using factor analysis. As a rule of thumb, Cronbach's alpha greater than or equal to $70 \%$ for Likert scale and Kuder-Richardson (KR-20) greater than or equal to $60 \%$ for binary scale, as it is not uncommon in exploratory research, accepted for the degree to which the measurement instrument succeeds in describing research interest (Chronbach, 1951).

Secondary data were collected from commercial banks' audited financial statements and national bank publications of economic indicators considered for the period covering from July 1, 1993 to June, 2016. To measure variables in secondary data, financial ratios were applied.

\subsection{Measurement instruments}

The research variables' indicators used in the survey instrument were measured by Likert and binary scale questions. The survey questionnaires and data collection method from secondary data stated below were adopted from Tessema and Kruger (2016).

\subsubsection{Measurement instruments used to collect primary data using survey questionnaires}

Measurement instruments of credit risk and liquidity crunch, investor loan funding, discrete market deposit interest rate incentive, and AIRCABS used to collect primary data (see Appendix 1, Table 1-4).

\subsubsection{Measures of continuous data type instruments applied in the models}

Ratios used to collect secondary data of liquidity crunch, credit risk, investor loan funding, discrete market deposit interest incentive and AIRCABS from financial statements and economic indicators (see Appendix 2, Table 5-9). 


\subsection{Method of analysis}

To investigate the impact of credit risk and liquidity crunch on an interest rate commission agent banking system, canonical correlation was used. To predict the relationship between investor loan funding and sustainability and profitability of AIRCABS, on the one hand, discrete market deposit interest incentive and stable deposit mobilization in bank, on the other hand, multinomial logistic regression used.

\subsubsection{Canonical correlation analysis}

The correlations between the linear combinations defined as canonical correlations. The linear combination of credit risk and liquidity crunch variables $(u)$ with a group of set of AIRCABS $(W)$ by using each set of variables can construct credit risk and liquidity crunch and AIRCABS variants by the following equations:

$$
\begin{aligned}
& {\left[\begin{array}{l}
\text { Credit risk } \\
\text { and credit } \\
\text { crunch }
\end{array}\right] \cdot u_{1}=a_{11} \cdot\left(\frac{\Delta D}{T D}\right)_{1}+a_{12} \cdot\left(\frac{\Delta L}{T L}\right)_{2}+a_{13} \cdot\left(\frac{L A}{T D}\right)_{3}+a_{14} \cdot\left(\frac{N P L s}{T L}\right)_{4}+a_{15} \cdot\left(\frac{L L P}{T L}\right)_{5}+a_{16} \cdot\left(\frac{\Delta p}{p}\right)_{6}} \\
& {\left[\begin{array}{l}
\text { Credit risk } \\
\text { and credit } \\
\text { crunch }
\end{array}\right] \cdot u_{2}=a_{21} \cdot\left(\frac{\Delta D}{T D}\right)_{1}+a_{22} \cdot\left(\frac{\Delta L}{T L}\right)_{2}+a_{23} \cdot\left(\frac{L A}{T D}\right)_{3}+a_{24} \cdot\left(\frac{N P L s}{T L}\right)_{4}+a_{25} \cdot\left(\frac{L L P}{T L}\right)_{5}+a_{26} \cdot\left(\frac{\Delta p}{p}\right)_{6}}
\end{aligned}
$$

$$
\begin{aligned}
& {\left[\begin{array}{l}
\text { Credit risk } \\
\text { and credit } \\
\text { crunch }
\end{array}\right] \cdot u_{p}=a_{p 1} \cdot\left(\frac{\Delta D}{T D}\right)_{1}+a_{p 2} \cdot\left(\frac{\Delta L}{T L}\right)_{2}+a_{p 3} \cdot\left(\frac{L A}{T D}\right)_{3}+a_{p 4} \cdot\left(\frac{N P L s}{T L}\right)_{4}+a_{p 5} \cdot\left(\frac{L L P}{T L}\right)_{5}+a_{p 6} \cdot\left(\frac{\Delta p}{p}\right)_{6}} \\
& \operatorname{AIRCABS}\left(W_{1}\right)=b_{11} \cdot(N I N)_{1}+b_{12} \cdot(E F R)_{2}+b_{13} \cdot(R O A)_{3}+b_{14} \cdot(R O E)_{4}+b_{15} \cdot(C A)_{5} \\
& \operatorname{AIRCABS}\left(W_{2}\right)=b_{21} \cdot(N I N)_{1}+b_{22} \cdot(E F R)_{2}+b_{23} \cdot(R O A)_{3}+b_{24} \cdot(R O E)_{4}+b_{25} \cdot(C A)_{5},
\end{aligned}
$$

$$
\operatorname{AIRCABS}\left(W_{q}\right)=b_{q 1} \cdot(N I N)_{1}+b_{q 2} \cdot(E F R)_{2}+b_{q 3} \cdot(R O A)_{3}+b_{q 4} \cdot(R O E)_{4}+b_{q 5} \cdot(C A)_{5},
$$

where $A_{t}$ and $B_{t}$ are canonical weights. 
In the maximization process, there are $p X$ and $q Y$ pairs of variables, respectively, such as $p \leq q$ for which maximum $p$ canonical correlations are generated. Consider for $\mathrm{p}$ vectors of $\mathrm{U}$ and $\mathrm{W}$ variates are sampled, such as $S_{x x}$ and $S_{y y}$ which are within-set variance-covariance matrices and $S_{x y}$ is a covariance matrix for the vectors $X$ and $Y$, which sum to unity to make $S_{x x}$ and $S_{y y}$ singular, which is calculated by eliminating one variable from each set and the (p-1) and (q-1) variables will be paired.

Canonical correlation between credit risk and liquidity crunch and AIRCABS dependes on the level of significance, magnitude of canonical root and redundancy index (Hair, Anderson, Tatham, \& Black, 1998). However, the research study interest is to find the null hypothesis true to find no relationship between independent variables, credit risk and liquidity crunch, and dependent variable, AIRCABS, and the regression coefficients except for the intercepts are all equal to zero.

To arrive at a single redundancy index, all redundancies across all root can be summed, otherwise, the first significant root can be considered as proposed by Stewart and Love (1968). However, the redundancy of coefficient that explained less than $10 \%$ of the remaining variance, after that, was explained by a certain number of functions considered as significant non-correlation (Sherry \& Henson, 2005).

The three methods of determining the relative importance of the canonical function of relationship are canonical weights, canonical loading and canonical cross loading. Among all the methods, some authors considered canonical loading as alternate to cross-canonical loading to interpret the result (Thompson, 1991, Liu, Drane, Liu, Wu, 2009; Hair, Anderson, Tatham, Black, 1998). However, this research study considered both canonical loading and cross-loading to interpret the result if the data became adequate and significant relationship existed between independents and dependent variables which let to proceed factor analysis.

Rotation in canonical correlation led to lose the optimal interpretation of the analysis. However, canonical functions, canonical loadings, and standardized canonical coefficients interpreted using Kaiser's (1974) normalized varimax rotation criterion.

While testing the correlation to avoid type I error, the significance value to interpret the result is set at a $95 \%$ confidence interval level. To interpret the magnitude or practical significance of the results, the value of squared canonical correlation that has the value $1.96 \%$ for small, $13.04 \%$ for medium and $25.92 \%$ for large and partial correlation has the value $14 \%, 36 \%$ and $51 \%$, respectively (Cohen, 1992).

The data for canonical correlation were analyzed using statistical software called SPSS.

\subsubsection{Multinomial logistic regressions analysis}

To investigate whether investor loan funding has a relationship with profitability and sustainability and discrete market deposit interest rate has a relationship with stable deposit in a bank, dependent variable was considered as a categorical variable for which data entered into the analysis as dummy coding 1 for the existence of profitability and sustainability; 0 for the non-existence of profitability and sustainability. Similarly, stable deposit was considered as a categorical variable for which the data entered into the analysis as dummy coding 1 for the existence of stable deposit, whereas 0 for the non-existence of stable deposit. When the value of predicting coefficient is equal to zero in the multinomial logistic regression model, the hypothesis under testing is said to be the null hypothesis, no relationship exists between the predicted independent variable and the value of the predicted dependent variable outcome, which mean that the independent variables do not predict closer to the value of the dependent variable. However, the significance of the hypothesis is that at least one of the coefficient values of the predictors is greater than zero and closer to the value of the predicted dependent variable outcome.

To identify which of independent variables' indicators were predictors of dependent variable, profitability and sustainability of an agent bank in the market in the first alternative research hypothesis are depicted by the following multinomial logistic regression equation: 
$\log \left[\frac{G P S(p=1)}{1-G P S(p=1)}\right]=a+b_{1} I L F+b_{2} \frac{M 2}{G D P}+b_{3} \frac{G N I}{P o p n}+b_{4} \frac{T S}{G D P}+b_{5} \frac{G P D I}{T B D}+b_{6} \frac{N I E}{N I I}$,

where gross profitability and sustainability (GPS) calculated based on return on capital (ROC) which in turn calculated total profit as percentage of total capital and the result of which interpreted as greater than

$0\left(\frac{\Delta R O C}{R O C}>0\right)$ for presence of GPS and less than or equal to $0\left(\frac{\triangle R O C}{R O C} \leq 0\right)$ for absence of GPS. Investor loan funding (ILF): calculated total loan as percentage of total deposits.

Similarly, which of independent variables were good predictors of dependent variable, stable deposit mobilization, in the second alternative research hypotheses, depicted by the following multinomial logistic regression equation:

$$
\begin{aligned}
& \log \left[\frac{S D(p=1)}{1-S D(p=1)}\right]=a+b_{1} \cdot D M D I+ \\
& +b_{2} \cdot A V D R+b_{3} \cdot S P D R+b_{4} \cdot D I I R+ \\
& +b_{5} \cdot E D U R+b_{6} \cdot D I P C
\end{aligned}
$$

where $a$ is the $y(G P S$ or SD) intercept and $b$ is the parameter which lay between interval $(0,1)$; stable deposit (SD) calculated as the change in deposit (CD) less average deposit (AD), which can be interpreted as stable deposit greater than $0(\triangle C D-A D>0)$ as a presence of SD and less than $0(\triangle C D-A D<0)$ as absence of SD since the change should be greater than the average deposit; discrete market deposit interest incentive (DMDI) calculated as change in ordinary saving deposit interest rate as a percentage of the period interest rate. Since the minimum deposit interest rate was determined by National Bank of Ethiopia, the change in interest rate was not frequent.

To assess the fit of the model against data collected to test the hypotheses, four inferential tests, such as Brown chi-square, the Pearson chi-square, de- viance-based and descriptive measures were adopted (Brown, 1982, Prentice, 1976; Hosmer \& Lemeshow, 2000).

\subsubsection{Mixing individual survey respondents' perception with quantitative data analysis result}

Though the research study focused on positivist research philosophy, explains the quantitative result of the study with support of human perception on survey instruments to answer the same research question, mixed method was applied. Integrating the quantitative result of the study with individual survey respondents' perception helped to explore the best method in strengthening problem-centered findings of the research study by overcoming the weaknesses of qualitative/quantitative method with the strengths of qualitative/quantitative method (Creswell, 2003; Castro, Kellison, Boyd, \& Kopak, 2010).

Coefficient of variation, calculated as the standard deviation as proportion of mean or standard error estimate as proportion to the estimate itself, was applied to measure the precision of individual survey respondents to the point of survey instruments. Though coefficient of variation does not measure bias due to non-response bias, it measures the precision of estimated mean and can be applied as estimator of population parameter (Schouten, Calinescu, \& luiten, 2013). It is used to compare samples of data from the same variables when mean measures were very different (Lovie, 2005). It is a measure of relative variability of positive random variable distribution whose standard deviation is less than the mean to show the reliability of the respondents' perception to the point of survey instruments (Pryseley, Mintiens, Knapen, Stede, \& Molenberghs, 2010). It is applied in finance to determine the relative risk to choose the best alternative investments. The higher the coefficient of variation means the deviation from central mean is high (Curto \& Pinto, 2009). Though the coefficient of variation measure is widely applied in the field of science, it is not widely applied in social science (Kelley, 2007). Because of this fact, the threshold of the coefficient of variation 
was not fixed at some referral point to interpret the individuals' point of agreement with survey instruments. To analyze the survey respondents' agreement or disagreement in the research study, the coefficient of variation reference point was set based on the significant level of parameter estimated using quantitative data. Accordingly, the maximum level of Likert scale survey questionnaire set as below or equal to .30 was considered as acceptable rates while the coefficient of variation above .30 was considered to be explained in caution referring to the mean. On the other hand, for the binary survey questionnaire of the research study, coefficient of variation set as below or equal to .50 was considered as acceptable rate, while a ratio above .50 was explained in caution referring to the mean of the survey instruments.

\section{STATISTICAL RESULT AND ANALYSIS}

Though the research study focused on positivist research philosophy, the individual perception gathered using survey questionnaires analyzed together with the quantitative result to answer the question of the research study.

The following section detailed how the validity and reliability was constructed to measure the perception of individual survey participants. To identify the strong relationship between the independent variables, credit risk and liquidity crunch, and dependent variable, AIRCABS, canonical correlation statistical result discussed in section 4.2 was followed by multinomial logistic statistical results that showed prediction of profitability and sustainability of AIRCABS using investor loan funding and of stable deposit mobilization using discrete market deposit interest incentive discussed in section 4.3.

\subsection{Validity and reliability of survey instruments}

\subsubsection{The statistical result of individual perception responses on credit risk and liquidity crunch survey instruments}

The quality of measuring instrument of survey questionnaires can be ascertained by testing for validity and reliability. However, getting the measuring instrument's validity, in turn, enables to ensure its reliability. The internal consistency of items in instruments measurement was assessed by Cronbach's alpha measuring statistical tool (Cronbach, 1951). The alpha measures the interrelatedness of items in the survey instrument even though it is affected by the test length and dimensionality, because it is not sufficient to measure the homogeneity or unidimensionality of test items in survey instruments (Cortina, 1993; Green, Lissitz, Mulaik, 1977). The result of Cronbach's alpha that indicates high interrelation among a group of variables helped to determine the requirement to proceed further analysis using factor analysis to test the construct validity of the questionnaires (Ratray \& Jones, 2007). Since factor analysis considered for dimension reduction technique in search of underlying unobservable (latent) variables that are reflected in the observed variables and identification of maximally correlated items in survey instruments, considering additional test such as mean, standard deviation and coefficient of variation helped to construct validity of items in survey instruments (Tate, 2003).

The Cronbach's alpha value of Likert scale survey instruments were developed for credit risk and liquidity crunch, on the one hand, and interest rate commission agent banking system (AIRCABS), on the other hand, calculated as .820 and .789, respectively. Cronbanch's alpha value greater than .70 is acceptable to show how strong relationship established among the items of survey instruments of credit risk and liquidity crunch and survey instruments of AIRCABS.

Table 10 shows that participants got a higher mean score on credit risk and liquidity crunch's survey questionnaires with less variability relative to the mean. So that, individual participants' perception of credit risk and liquidity crunch survey instrument strongly agreed with the point of questions, Q1, Q2, Q4, Q5, Q6, Q7, Q8, Q10, Q11, Q12, Q13 and Q15, because the individual participants' perception was very close to the central mean. Whereas individuals perception's a little bit was found far from the central tendency on Q3, Q9, Q14 and Q16. 
Table 10. Descriptive statistics for credit risk and liquidity crunch

\begin{tabular}{|c|c|c|c|}
\hline Descriptive statistic & Mean & $\begin{array}{l}\text { Std. } \\
\text { Deviation }\end{array}$ & $\begin{array}{l}\text { Coefficient } \\
\text { of variation }\end{array}$ \\
\hline Decrement of bank's loan growth and capital is a sign of liquidity crunch (Q1) & 3.77 & 1.032 & .27 \\
\hline $\begin{array}{l}\text { Bank lending practices that lead borrower more vulnerable to abusive practice } \\
\text { enhance liquidity crunch (Q2) }\end{array}$ & 3.71 & 0.985 & .27 \\
\hline $\begin{array}{l}\text { The bank that involved in high level of interest income exposed to liquidity } \\
\text { crunch }(\mathrm{Q} 3)\end{array}$ & 3.16 & 1.101 & .35 \\
\hline The misjudgment of bank strategic increases the bank liquidity risk (Q4) & 4.08 & 0.995 & .24 \\
\hline Bank failures sourced from effect of deposit run (Q5) & 3.63 & 1.029 & .28 \\
\hline $\begin{array}{l}\text { High illiquid asset that is unaccepted for common valuation in market is the } \\
\text { source liquidity risk (Q6) }\end{array}$ & 3.67 & 0.966 & .26 \\
\hline Instability of depositors led the bank to liquidity risk (Q7) & 4.10 & 0.990 & .24 \\
\hline $\begin{array}{l}\text { Diversifying loan funded by bank out of intended purpose led the borrower to } \\
\text { defaulter (Q8) }\end{array}$ & 3.87 & 1.151 & .30 \\
\hline $\begin{array}{l}\text { Funding loan by bank to entrepreneur as own asset increases the bank's credit } \\
\text { risk }(Q 9)\end{array}$ & 3.27 & 1.105 & .34 \\
\hline Credit operation weakness of borrower leads the loan to default (Q10) & 3.99 & 0.998 & .25 \\
\hline Loan sanctioned by corruption lead borrower to default (Q11) & 4.06 & 1.053 & .26 \\
\hline $\begin{array}{l}\text { Lack of good credit assessment and follow up by bank lead to increase non- } \\
\text { performing asset (Q12) }\end{array}$ & 4.25 & 1.102 & .26 \\
\hline Borrowers default for lack of management support from credit institutions (Q13) & 3.69 & 0.993 & .27 \\
\hline Buying and selling of money exposed the bank to credit risk (Q14) & 3.17 & 1.034 & .33 \\
\hline $\begin{array}{l}\text { Decline of commodity prices for exporters, who used bank loan facility, can } \\
\text { result higher nonperforming loans (NPLs) (Q15) }\end{array}$ & 3.92 & 1.004 & .26 \\
\hline As capital adequacy increases credit risk of the bank decreases (Q16) & 3.53 & 1.156 & .33 \\
\hline
\end{tabular}

Similarly, in Table 11 the participant got high mean scores on AIRCABS survey questionnaires with less variability relative to mean even though individuals participant's perception on AIRCABS survey instrument strongly agreed with the point of questions Q2, Q3, Q4, Q5, Q6, $\mathrm{Q} 7$ and $\mathrm{Q} 8$, because individual respondents' perception was very close to central mean. However, individual participants' perception was found a little bit far from central tendency on questionnaires, Q1 and Q9. This indicated that as coefficient variation getting lower than .30 the participants agreed with the research interest, which, in turn, implied that the majority of the respondents agreed with points of items in the survey instruments.

Table 11. Descriptive statistics for AIRCABS

\begin{tabular}{|c|c|c|c|}
\hline Descriptive statistic & Mean & $\begin{array}{l}\text { Std. } \\
\text { Deviation }\end{array}$ & $\begin{array}{l}\text { Coefficient } \\
\text { of variation }\end{array}$ \\
\hline $\begin{array}{l}\text { The bank's buying and selling of fund deprived the depositor's to get credit price } \\
\text { (Q1) }\end{array}$ & 3.3066 & 1.10785 & 0.335042 \\
\hline $\begin{array}{l}\text { As deposit and credit interest rate approach equilibrium point the bank } \\
\text { shall work as an interest rate commission agent for investor loan funding to } \\
\text { entrepreneur to enhance its sustainability in market }(\mathrm{Q} 2)\end{array}$ & 3.6772 & 0.97919 & 0.266287 \\
\hline $\begin{array}{l}\text { Providing alternative investment opportunity to fund provider by AIRCABS } \\
\text { enable to enhance stable fund in the bank (Q3) }\end{array}$ & 3.8531 & 0.86619 & 0.224803 \\
\hline $\begin{array}{l}\text { Providing high deposit interest rate and credit price by AIRCABS enable the bank } \\
\text { to attract funds from the unbanked and banked society (Q4) }\end{array}$ & 3.7631 & 0.93847 & 0.249387 \\
\hline $\begin{array}{l}\text { Administering investor loan funding through AIRCABS enable to eradicate } \\
\text { liquidity crunch (Q5) }\end{array}$ & 3.5455 & 0.98926 & 0.279018 \\
\hline $\begin{array}{l}\text { Bank can transfer credit risk using AIRCABS to the fund holder and investor to } \\
\text { increase its profitability and sustainability (Q6) }\end{array}$ & 3.7359 & 0.93081 & 0.249153 \\
\hline $\begin{array}{l}\text { AIRCABS enables the fund owner to search potential borrowers with or without } \\
\text { collateral in the market to provide a credit facility using the bank as an agent (Q7) }\end{array}$ & 3.8077 & 0.86333 & 0.226733 \\
\hline $\begin{array}{l}\text { The right of the investor and depositors to get their fund return will be safely kept } \\
\text { by the bank using AIRCABS (Q8) }\end{array}$ & 3.6119 & 0.96231 & 0.266428 \\
\hline $\begin{array}{l}\text { Under AIRCABS, the bank's profit will be simply maximized without financial } \\
\text { expense (Q9) }\end{array}$ & 3.2727 & 1.19462 & 0.365026 \\
\hline
\end{tabular}


The KMO value greater than .60 represented the ratio of the squared correlation between variables to the squared partial correlation between variables (Field, 2009, p. 647). As indicated in Table 12 below, KMO test result for measuring instruments of credit risk and liquidity crunch, on the one hand, and AIRCABS, on the other hand, were .885 and .828 , respectively. These results implied that the partial correlation among measurement instruments was high and the participants' responses in the sample were adequate. The Bartlett's test of sphericity Chi-square for credit risk and liquidity crunch and AIRCABS were 1068.78 and 635.784, respectively. KMO and Bartlett's test of credit risk and liquidity crunch and AIRCABS were significant at $\mathrm{P}=.000$ and $\mathrm{P}=.000$, respectively, which were below the standard significant level $(\mathrm{P}<.05)$. This implied that the correlation matrix was not an identity matrix that a matrix of all diagonal elements are neither one nor all off diagonal elements closer to zero. So the measurement instrument used in data analysis had a strong relationship.

Table 12. KMO and Bartlett's test

\begin{tabular}{|c|c|c|c|}
\hline \multicolumn{3}{|c|}{ Credit risk and liquidity crunch } & AIRCABS \\
\hline \multicolumn{2}{|c|}{$\begin{array}{l}\text { Kaiser-Meyer-Olkin measure } \\
\text { of sampling adequacy }\end{array}$} & .885 & .828 \\
\hline \multirow{3}{*}{$\begin{array}{l}\text { Bartlett's test } \\
\text { of sphericity }\end{array}$} & $\begin{array}{l}\text { Approx. } \\
\text { Chi-square }\end{array}$ & 1068.781 & 635.784 \\
\hline & Df & 120 & 36 \\
\hline & Sig. & .000 & .000 \\
\hline
\end{tabular}

KMO and Bartlett's test result for credit risk and liquidity crunch, on the one hand, and AIRCABS, on the other hand, showed a strong relationship among items in survey instruments. These resultshelped to proceed further factor analysis to construct validity of survey instruments.

\section{Factor analysis for validity of credit risk and liquidity crunch and AIRCABS survey questionnaires}

In analyzing variance of survey instruments, the dimension of credit risk and liquidity crunch survey instruments was reduced and five factors were retained from the total of 16 , and the dimension of AIRCABS survey questionnaires was reduced and three factors were retained from the total of nine factors. The retained factors whose eigenval- ues greater than 1 considered for further factorial analysis, since the estimated variance explained by factors was more than the average variances in a data set. Accordingly, factors of credit risk and liquidity crunch and AIRCABS whose eigenvalue greater than 1 accounted for $84.26 \%$ and $76.175 \%$ of the total variances, respectively, which, in turn, implied that the factors were reliable and highly defined.

The rotated component matrix reduced the numbers of factors to make further analysis of credit risk and liquidity crunch and AIRCABS scale dimensions easier. Since KMO is significant, the data collected using measurement instruments were factorial and factor loading greater than .50 which approached to one for each survey instrument obtained. As the value of the factor loading approached to 1 , the variables correlation with that factor increased. The strong correlation between the variables and the factorial loading was created when variables loaded highly on that factor. This indicates that the data demonistrated factorial validity where diferent insrument's measurment of credit risk and liquidity crunch and AIRCABS that stand to measure a particuar dimension within the domain of survey instruments were highly correlated (Engel \& Schutt, 2013). So the extracted five foctors for credit risk and liquidity crunch, on the one hand, and three factors for AIRCABS were found uni-dimensional and factorially distinct. All items used to operationalize a particular construct were loaded onto a single factor. So each survey questionnaire of credit risk and liquidity crunch and AIRCABS have a strong correlation with selected component's loadings.

\subsubsection{Investor loan funding}

The alpha value of investor loan funding was .616 and the alpha value for discrete market deposit interest incentive was .701. Though the minimum requirement alpha value of Likert scale items was .70 and more, the alpha value .60 and more was not uncommon in exploratory research. Salvucci, Walter, Conley, Fink, and Saba (1997) calculated a range of reliability measures of alpha value between .50 and .80 , as moderate and alpha value above .80 were stated as highly reliable. So the alpha value of Kuder-Richardson test results obtained allowed to proceed factor analysis to con- 
Table 13. Model summary rotation ${ }^{\mathrm{a}}$

\begin{tabular}{|c|c|c|c|c|c|c|}
\hline \multicolumn{4}{|c|}{ Investor loan funding } & \multicolumn{3}{|c|}{ Discrete market deposit interest incentive } \\
\hline \multirow{2}{*}{ Dimension } & \multirow{2}{*}{$\begin{array}{c}\text { Cronbach's } \\
\text { alpha }\end{array}$} & \multicolumn{2}{|c|}{ Variance accounted for } & \multirow{2}{*}{$\begin{array}{c}\text { Cronbach's } \\
\text { alpha }\end{array}$} & \multicolumn{2}{|c|}{ Variance accounted for } \\
\hline & & $\begin{array}{c}\text { Total } \\
\text { (eigenvalue) }\end{array}$ & $\begin{array}{c}\% \text { of } \\
\text { variance }\end{array}$ & & $\begin{array}{c}\text { Total } \\
\text { (eigenvalue) }\end{array}$ & $\begin{array}{c}\% \text { of } \\
\text { variance }\end{array}$ \\
\hline 1 & .986 & 4.137 & 68.949 & .997 & 2.825 & 56.496 \\
\hline 2 & .966 & 1.863 & 31.051 & .996 & 2.175 & 43.504 \\
\hline Total & $1.000 \mathrm{~b}$ & 6.000 & 100.000 & $1.000 \mathrm{~b}$ & 5.00 & 100 \\
\hline
\end{tabular}

Note: a - rotation method: varimax with Kaiser normalization, b - Total Cronbach's alpha is based on the total eigenvalue.

struct validity of survey questionnaires.

\section{Factor analysis for validity of investor loan funding and discrete market deposit interest incentive survey questionnaires}

Items in the survey questionnaires of investor loan funding and discrete market deposit interest rate incentive were further analyzed using factor analysis to reveal the validity of the survey instruments. Table 13 depicted the investor loan funding's Cronbanch's alpha values of dimension 1 as .986 and dimension 2 as .966 . The total variance accounted for dimension 1 was $68.949 \%$ and dimension 2 was $31.051 \%$. The higher eigenvalue that helped to determine the percentage of variance accounted for $68.949 \%$ in the optimally binary response items considered over the smaller one, dimension 2. Similarly, the Cronbach's alpha value for discrete market deposit interest rate incentive in dimension 1 was .997 and in dimension 2 was .996. The total variance accounted for dimension 1 was $56.50 \%$. Whereas, for dimension 2 , accounted for $43.50 \%$. The higher eigenvalue, dimension 1 , whose variance accounted for $56.50 \%$ was considered over dimension 2.

Once significant - Cronbach's alpha value and percentage of variance were identified on the survey questionnaires, the one whose variation displayed less $10 \%$ excluded from analysis. Table 14 and 15 displayed the coordination of each survey questionnaire in relation to the centroid $(0,0)$ when all survey questionnaires items were represented by a straight line between dimentsion 1 and dimension 2 . All survey instruments whose mean value is greater than $10 \%$ have a substantial contribution to the principal components. So all investor loan

Table 14. Variance accounted for

\begin{tabular}{|c|c|c|c|c|c|c|}
\hline \multirow{3}{*}{ Investor loan funding survey instruments } & \multicolumn{3}{|c|}{ Centroid coordinates } & \multicolumn{3}{|c|}{ Total (vector coordinates) } \\
\hline & \multicolumn{2}{|c|}{ Dimension } & \multirow{2}{*}{ Mean } & \multicolumn{2}{|c|}{ Dimension } & \multirow{2}{*}{ Total } \\
\hline & 1 & 2 & & 1 & 2 & \\
\hline $\begin{array}{l}\text { As the supply of loan funding by investor to entrepreneur's } \\
\text { increases through an interest rate commission agent bank } \\
\text { investment in a country enhances and thereby increases the } \\
\text { country GDP (Q5) }\end{array}$ & .994 & .149 & .571 & .993 & .007 & 1.000 \\
\hline $\begin{array}{l}\text { Funding loan by investor to entrepreneur through an interest } \\
\text { rate commission agent bank eliminates the bank exposure to } \\
\text { credit risk and liquidity crunch (Q4) }\end{array}$ & .993 & .131 & .562 & .993 & .007 & 1.000 \\
\hline $\begin{array}{l}\text { Investor loan funding increase the agent bank's profitability } \\
\text { in broad sample base (Q1) }\end{array}$ & .993 & .026 & .509 & .993 & .007 & 1.000 \\
\hline $\begin{array}{l}\text { Benefiting credit price to investor loan funding enhances the } \\
\text { agent bank interest rate commission }(\mathrm{Q} 6)\end{array}$ & .992 & .008 & .500 & .992 & .008 & 1.000 \\
\hline $\begin{array}{l}\text { Investor's loan funding enhances the bank liquidity and } \\
\text { efficiency (Q2) }\end{array}$ & .993 & .043 & .518 & .992 & .008 & 1.000 \\
\hline $\begin{array}{l}\text { Investor loan funding can enhance the bank's loan } \\
\text { administrative efficiency and capacity (Q3) }\end{array}$ & 1.000 & 1.000 & 1.000 & .755 & .245 & 1.000 \\
\hline Active total & 5.965 & 1.356 & 3.661 & 5.717 & .283 & 6.000 \\
\hline$\%$ of variance & 99.416 & 22.606 & 61.011 & 95.290 & 4.710 & 100.000 \\
\hline
\end{tabular}


Table 15. Variance accounted for

\begin{tabular}{|c|c|c|c|c|c|c|}
\hline \multirow{3}{*}{ Discrete market deposit survey instruments } & \multicolumn{3}{|c|}{ Centroid coordinates } & \multicolumn{3}{|c|}{ Total (vector coordinates) } \\
\hline & \multicolumn{2}{|c|}{ Dimension } & \multirow{2}{*}{ Mean } & \multicolumn{2}{|c|}{ Dimension } & \multirow{2}{*}{ Total } \\
\hline & 1 & 2 & & 1 & 2 & \\
\hline $\begin{array}{l}\text { Allowing depositor to participate in bank's investment } \\
\text { by paying proportionate credit price for their partial } \\
\text { or full fund enable the bank to have more stable fund } \\
\text { (Q4) }\end{array}$ & .999 & .281 & .640 & .998 & .002 & 1.000 \\
\hline $\begin{array}{l}\text { Applying various level deposit interest rate incentive } \\
\text { for depositors enable the bank to get more stable } \\
\text { deposit (Q3) }\end{array}$ & .998 & .085 & .541 & .998 & .002 & 1.000 \\
\hline $\begin{array}{l}\text { Interest incentive on deposit in terms of incentive in } \\
\text { kind enables the bank to hold more clientele (Q5) }\end{array}$ & .998 & .085 & .542 & .998 & .002 & 1.000 \\
\hline $\begin{array}{l}\text { The increase of deposit interest rate increases the } \\
\text { demand of the depositor (Q1) }\end{array}$ & .998 & .021 & .509 & .998 & .002 & 1.000 \\
\hline $\begin{array}{l}\text { Applying discrete market interest rate incentive for } \\
\text { those deposit's volume increases the demand of } \\
\text { depositor to keep their deposit stable increases (Q2) }\end{array}$ & 1.000 & 1.000 & 1.000 & .970 & .030 & 1.000 \\
\hline Active total & 4.993 & 1.472 & 3.233 & 4.962 & .038 & 5.000 \\
\hline$\%$ of variance & 99.867 & 29.442 & 64.655 & 99.244 & .756 & 100.000 \\
\hline
\end{tabular}

funding and discrete market deposit interest incentive items in survey instruments strongly contributed to the principal components that made them considered in the analysis.

Since investor loan funding and discrete market deposit interest incentive survey questionnaires items' eigenvalue approached to 1 , high inter-correlation was found with factor one and was less loaded to the second factor, respectively.

Based on the significant result of Cronbach's alpha to proceed factor analysis, all factor loading found greater than .50 and the measurement instruments of investor loan funding and discrete market deposit interest rate incentive were found reliable and valid. This implied that the survey in- struments developed were correct for data collection and for analysis of individuals' perception.

\subsection{Canonical correlation statistical result}

The relationship between credit risk and liquidity crunch, on the one hand, and an interest rate commission agent banking system, on the other hand, identified using Canonical correlation to answer the research question of the following hypothesis.

H0: Credit risk and liquidity crunch have no positive effect on an interest rate commission agent banking system in administrating investors loan funding to entrepreneurs.

Table 16. Descriptive statistics for credit risk and liquidity crunch and AIRCABS

\begin{tabular}{|c|c|c|c|c|c|c|c|c|c|c|}
\hline 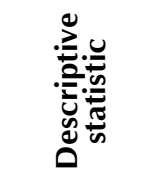 & 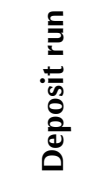 & 흥을 & 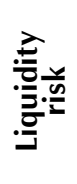 & 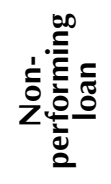 & 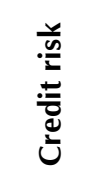 & 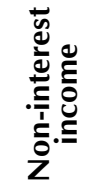 & 兰 & 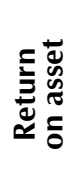 & 들 등 흥 & 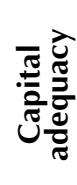 \\
\hline Mean & 0.16 & 0.15 & 0.54 & 0.0288 & -4.045 & 0.0739 & 2.13 & 3.85 & 0.56 & 10.83 \\
\hline $\begin{array}{l}\text { Std } \\
\text { deviation }\end{array}$ & 0.1001 & 0.1 & 0.62 & 0.0565 & 17.99 & 0.069 & 1.02 & 0.66 & 0.24 & 28.51 \\
\hline $\begin{array}{l}\text { Coefficient } \\
\text { of variation }\end{array}$ & 0.63 & 0.67 & 1.15 & 1.96 & -4.45 & 0.93 & 0.48 & 0.17 & 0.43 & 2.63 \\
\hline
\end{tabular}


Table 17. Linear combination for canonical correlation

\begin{tabular}{|c|c|c|c|c|c|c|}
\hline Covariate & $\underset{\text { run }}{\text { Deposit }}$ & $\begin{array}{l}\text { Credit } \\
\text { crunch }\end{array}$ & $\begin{array}{l}\text { Liquidity } \\
\text { risk }\end{array}$ & $\begin{array}{c}\text { Non-performing } \\
\text { asset }\end{array}$ & $\begin{array}{l}\text { Credit } \\
\text { risk }\end{array}$ & $\begin{array}{l}\text { Commodity } \\
\text { price shock }\end{array}$ \\
\hline \multirow{2}{*}{ Non-interest income } & -0.287 & 0.718 & -0.264 & -0.0685 & -1.85 & -0.283 \\
\hline & $0.778^{*}$ & $0.484^{*}$ & $0.796^{*}$ & $0.946^{*}$ & $0.085^{*}$ & $0.781^{*}$ \\
\hline \multirow{2}{*}{ Bank efficiency } & -0.354 & -0.224 & 1.332 & -0.965 & -1.628 & -0.247 \\
\hline & $0.728^{*}$ & $0.826^{*}$ & $0.204^{*}$ & $0.351^{*}$ & $0.126^{*}$ & $0.808^{*}$ \\
\hline \multirow{2}{*}{ Return on asset } & 0.536 & 0.9507 & -0.878 & -0.361 & -0.503 & -0.908 \\
\hline & $0.6^{*}$ & $0.358^{*}$ & $0.395^{*}$ & $0.723^{*}$ & $0.623^{*}$ & $0.379^{*}$ \\
\hline \multirow{2}{*}{ Return on equity } & -1.059 & 0.935 & -0.653 & 0.265 & 0.939 & 0.226 \\
\hline & $0.307^{*}$ & $0.366^{*}$ & $0.524^{*}$ & $0.795^{*}$ & $0.363^{*}$ & $0.824^{*}$ \\
\hline \multirow{2}{*}{ Capital adequacy } & 0.613 & 0.758 & -0.487 & -0.214 & -0.575 & -0.023 \\
\hline & $0.55^{*}$ & $0.461^{*}$ & $0.634^{*}$ & $0.834^{*}$ & $0.575^{*}$ & $0.982^{*}$ \\
\hline
\end{tabular}

Note: ${ }^{\star}$ Ratio of $\mathrm{t}$-value with non-significant $\mathrm{P}>\mathrm{I} \mathrm{t} \mathrm{I}$.

To investigate the impact of credit risk and liquidity crunch (deposit run, credit crunch, liquidity risk, non-performing asset and credit risk) on AIRCABS (non-interest income, bank efficiency, return on asset, return on equity and capital adequacy) the following mean and standard deviation developed to ascertain the variables' deviation from the central tendency.

As discussed in Table 16, the relationship between independent variables, credit risk and liquidity crunch, and dependent variables, AIRCABS, was described by simple statistical mean and standard deviation. A very high deviation of variables from central tendency has made a great diversity of variables uncorrelated. Since the standard deviation of liquidity risk, nonperforming loan, credit risk, bank efficiency and capital adequacy were greater than their mean value, there was seen high variability of variables from central tendency except return on asset variables.

Canonical correlation interpreted by the level of significance, the size of canonical correlation and the magnitude of redundancy index. To investigate further the relationship between independent variables, credit risk and liquidity crunch, and dependent variable, AIRCABS, simple statistical correlation conducted by the following table 18 .

\subsubsection{Level of significance of canonical correlation}

As was indicated in Table 17, the t-value, followed by $\mathrm{t}$-distribution to test the null hypothesis that canonical coefficients of independent and dependent variables were zero. Since the probability of $\mathrm{t}$ statistics was greater than the alpha level (.05), the canonical correlation coefficient between independent and dependent variables found zero. This, in turn, implied that there no established linear relationship between independent variables, credit risk and liquidity crunch, and dependent variables, AIRCABS. Accordingly, items neither on independent side nor on dependent sides created correlation with one another. So the null hypothesis that there was no relationship between credit risk and liquidity crunch on the one hand, and AIRCABS, on the other hand, was accepted. However, additional analysis to investigate the relationship between independent and dependent variables conducted.

Table 18. Multivariate tests of significance

\begin{tabular}{|c|c|c|c|}
\hline Test name & Value & Approx. F & Sig. of $F$ \\
\hline Pillais & 1.24510 & 65.00 & $.839 *$ \\
\hline Hotellings & 2.66393 & 37.00 & $.880^{*}$ \\
\hline Wilks & .17734 & 38.00 & $.856^{*}$ \\
\hline Roys & .65825 & & \\
\hline
\end{tabular}

Note: ${ }^{\star}$ non-significant $\mathrm{P}>.05$. 
Table 19. Dimension reduction analysis

\begin{tabular}{|c|c|c|c|}
\hline Canonical function & Wilks L. & $\mathbf{F}$ & Sig. of $F$ \\
\hline $1 \mathrm{TO} 5$ & .17734 & .68525 & $.856^{*}$ \\
\hline 2 TO 5 & .51892 & .37308 & $.989^{*}$ \\
\hline 3 TO 5 & .69149 & .36651 & $.965^{*}$ \\
\hline 4 TO 5 & .87344 & .27999 & $.941^{*}$ \\
\hline 5 TO 5 & .97734 & .15070 & $.862^{*}$ \\
\hline
\end{tabular}

Note: ${ }^{\star}$ non-significant $\mathrm{P}>0.05$.

The result indicated in the above table is a separate test of each canonical function that all canonical roots evaluated as non-significant and the model didn't fit the data according to multivariate criterion report of Pillais, Hotellings, Wilks and Roy.

In Table 19, multivariate statistical test showed that the model is not generally a fit model and extracted five canonical roots were not significantly correlated and dependent on one another.

Generally, all the statistical result showed that test of canonical correlation between independent, credit risk and liquidity crunch, and the dependent variables, AIRCABS, found insignificant relationship and the null hypothesis of the research study was accepted.

\subsubsection{The magnitude of canonical correlation}

The significant level of canonical function is based on the size of canonical correlation. Though no accepted rules established either to accept or reject the size of canonical correlation, the research study based on the significant level of multivariate test and factor analysis. To run factor analysis, the sampling adequacy and model fit test were conducted using KaiserMeyer-olkin and Bartlett's test as follows.
Table 20. KMO and Bartlett's test

\begin{tabular}{|c|c|c|}
\hline \multicolumn{2}{|c|}{$\begin{array}{l}\text { Kaiser-Meyer-Olkin measure of sampling } \\
\text { adequacy }\end{array}$} & \multirow{2}{*}{$\frac{.320}{34.657}$} \\
\hline \multirow{3}{*}{$\begin{array}{l}\text { Bartlett's test of } \\
\text { sphericity }\end{array}$} & Approx. Chi-square & \\
\hline & Df & 45 \\
\hline & Sig. & .868 \\
\hline
\end{tabular}

As indicated in Table 20, the sampling adequacy is below the minimum requirement .60 and model fit test of Barteltt's test of Chi-square found insignificant at $\mathrm{P}=.868$, which was above the required significant level $(\mathrm{P}>05)$. The data were not suited to proceed factor analysis, because there was no relationship between independent variables, credit risk and liquidity crunch, and dependent variables, AIRCABS.

\subsubsection{Redundancy measure of share variances}

As indicated in Table 21 below, the share variance account for $65.83 \%$ of total shared variances between the canonical variables. However, squared canonical correlation did not represent the variance extracted from the sets of variables except the variance shared by the linear composites of the sets of dependent and independent variables (Alpert, Mark, \& Robert, 1972). As a matter of fact, instead of squared canonical correlation, redundancy index

Table 21. Redundancy index and effect of shared variance

\begin{tabular}{c|c|c|c|c}
\hline Root no & $\begin{array}{c}\text { Canonical } \\
\text { correlation }\end{array}$ & $\begin{array}{c}\text { Square correlation } \\
\left(\mathbf{R}_{c}^{2}\right)\end{array}$ & $\begin{array}{c}\text { Effect size } \\
\text { index(1- Wilks } \lambda)\end{array}$ & Redundancy index* \\
\hline $\mathbf{1}$ & $\mathbf{. 8 1 1 3 2}$ & $\mathbf{. 6 5 8 2 5}$ & $\mathbf{. 8 2 2 6 6}$ & $\mathbf{. 1 6 3 9}$ \\
\hline 2 & .49957 & .24957 & .48108 & .0621 \\
\hline 3 & .45641 & .20831 & .30851 & .0519 \\
\hline 4 & .32605 & .10631 & .32655 & .02266 \\
\hline 5 & .15053 & .02266 & & .0056 \\
\hline $\begin{array}{c}\text { Amount of shared } \\
\text { variance (SV) }\end{array}$ & & & & $24.902 \%$ \\
\hline
\end{tabular}

Note: ${ }^{*}(\mathrm{SV})\left(\mathrm{R}_{c}^{2}\right)$. 
Table 22. Model fitting information of profitability and sustainability of AIRCABS

\begin{tabular}{|c|c|c|c|c|c|c|}
\hline \multirow{2}{*}{ Model } & \multicolumn{3}{|c|}{ Model fitting criteria } & \multicolumn{3}{|c|}{ Likelihood ratio tests } \\
\hline & AIC & BIC & -2 Log Likelihood & Chi-square & Df & Sig. \\
\hline Intercept only & 23.930 & 24.703 & 21.930 & & & \\
\hline Final & 17.018 & 18.563 & 13.018 & 8.912 & 1 & .003 \\
\hline
\end{tabular}

was calculated to use as a measure of shared variance as proposed by Lambert and Durand (1975).

The redundancy index which measures the amount of share variance in the dependent variables explained by independent canonical variate is less than $10 \%$ of variance in their function except for the first canonical function, which was less impressive to interpret the corresponding canonical function, since the overall model was insignificant.

The proportion of variance shared between the variable sets across all functions calculated as $82.27 \%$ for full model which is higher than the first squared canonical correlation, $65.83 \%\left(=.81132^{2}\right)$, even though the sum of squared canonical correlation effect size always greater than the full model effect (Sherry \& Henson, 2005). This implied that the second function was not created after the first has explained by as much variability as observed variables. This indicates that no relationship found between variate of credit risk and liquidity crunch, on the one hand, and variate of AIRCABS, on the other hand.

Because of insignificant canonical correlation between independent and dependent variables the model did not fit the data and further interpretation of canonical root and redundancy index was not considered to reveal the significant size of original variables in canonical correlation using factor analysis.

As a result of a statistical test, the null hypothesis of the research study, credit risk and liquidity crunch have no impact on an interest rate commission agent banking system, was accepted.

\subsubsection{Individual perception of credit risk and liquidity crunch survey questionnaires}

As depicted in Table 16, dispersion of variables of credit risk and liquidity crunch and AIRCABS relative to the mean showed high variability. The variables' proportion of standard deviation to the mean that should have been less than 1 revealed no relation- ship between independent variables, credit risk and liquidity crunch (CRLC), and dependent variables, AIRCABS. Since we found no quantitative relationship between the independent and dependent variables, the suit of individual survey participants' perception with the point of survey question based on the coefficient of variation $(\mathrm{CV})$ cut off point below .30 fitted with the point of independent and dependent variables utilized in predicting their relationship in real world practice based on audited commercial banks' financial statements. Accordingly, all survey participants' perception whose CV less than or equal to .30 strongly agreed with point of questions except survey questionnaires CRLC-Q3 (CV.34), CRLC-Q9 (CV.33), CRLC-Q14 (CV.33), CRLC-Q16 (CV.33), AIRCABS-Q1 (CV.34) and AIRCABS-Q9 (CV.36) whose survey participants' perception a little bit far from central tendency.

The coefficient of variation calculated for the all survey questionnaires was very close to zero, as the individual survey participants' perception was very close to the central mean. Since all survey instruments assessed by the individual survey participants enhanced the contents of independent and dependent variables that applied in quantitative analysis, the mix of individual survey participants' perception and quantitative analysis of financial statement showed credit risk and liquidity crunch have no impact on an interest rate commission agent banking system.

Therefore, the null hypothesis that credit risk and liquidity crunches have no positive effect on an interest rate commission agent banking system was accepted.

\subsection{Statistical result of investor loan funding and discrete market deposit interest rate incentive}

Investor loan funding prediction of sustainability and profitability of AIRCABS and discrete mar- 
Table 23. Model fitting information of stable deposit

\begin{tabular}{|c|c|c|c|c|c|c|}
\hline \multirow{2}{*}{ Model } & \multicolumn{3}{|c|}{ Model fitting criteria } & \multicolumn{3}{|c|}{ Likelihood ratio tests } \\
\hline & $\mathrm{AIC}$ & $\mathrm{BIC}$ & -2 Log Likelihood & Chi-square & Df & Sig. \\
\hline Intercept only & 28.734 & 29.778 & 26.734 & & & \\
\hline Final & 13.411 & 15.500 & 9.411 & 17.323 & 1 & .000 \\
\hline
\end{tabular}

ket deposit interest incentive prediction of stable deposit mobilization was analyzed based on audited financial statement of commercial banks in Ethiopia to answer the question of the following research hypothesis:

H1: investors loan funding has a positive effect on profitability and sustainability of an interest rate commission agent banking system;

H2: discrete market deposit interest rate incentive has a positive effect on stable deposit mobilization in a bank.

\subsubsection{Model fitting information}

The model fitting information detailed the dependent and independent variables together with their control variables to assess the final model. To identify the relationship between sustainability and profitability of AIRCABS with investor loan funding, identifying the risk related within the predictor and predicted variables is vital (Bayaga, 2010). Analyzing the risk between independent and dependent variables using multinomial logistic regression helped to identify the overall relationship.

Tables 22 and 23 detailed the model fitting information of sustainability and profitability of AIRCABS which was predicted by investor loan funding together with its control variables, such as bank efficiency, return on asset, return on equity and capital adequacy. The Chi-square (8.912) in Table 22 and Chi-square (17.323) in Table 23 which were the difference between -2Log-likelihood of the null model and the final model found significant at $\mathrm{P}=.003$ and $\mathrm{P}=.000$, which are less than cut off $\mathrm{P}=0.05$. This accounted for the model fitted the data better and more accurately than a null model. The value of AIC and BIC, which are information theory based on the significant of model fitting the data were very close to $-2 \mathrm{Log}$ Likelihood both in Table 22 and Table 23. The closeness in distance among AIC, BIC and -2 Log Likelihood implied that the likelihood of the models to the true expected value. So the null hypothesis that can be stated as no difference between the model without independent variables and the model with independent variables was rejected and the alternative hypotheses ( $\mathrm{H} 1$ and $\mathrm{H} 2)$ of the research study were accepted.

\subsubsection{Goodness-of-fit}

Table 24 and Table 25 reported further evidence of statistical insignificant level of Pearson's correlation and deviance goodness-of-fit model. The Pearson's correlation and deviance for sustainability and profitability of AIRCABS and stable deposit were the difference between the current model and the full model whose null value were .376 and .525 (in Table 24) and .899 and .966 (in Table 25), respectively, greater than p-value $(0.05)$ that made the model a good overall fit to the data and predicted probabilities that did not deviate from the observed probabilities to the extent that binomial distribution did predict.

The independent ways by which independent variables predict the dependent variables using Pearson's correlation and deviance in Table 24 and in Table 25 based on the amount of information in the data that helped to estimate the value of unknown population parameters were $14(\mathrm{df})$ and 19(df), respectively. Insignificant of the goodnessof-fit model implied that independent variables, investor loan funding together with its control variables, predicted the dependent variables, sustainability and profitability of AIRCABS, as the insignificant result of Pearson's correlation and deviance stated in Table 24. On the other hand, the independent variables, discrete market deposit interest rate incentive, predicted the dependent variables, stable deposit mobilization, as the insignificant result of Pearson's correlation and deviance stated in Table 25. 
Table 24. Goodness-of-fit

\begin{tabular}{|c|c|c|c|c|c|c|}
\hline \multicolumn{4}{|c|}{ Profitability and sustainability of AIRCABS } & \multicolumn{3}{|c|}{ Stable deposit } \\
\hline & Chi-square & df & Sig. & Chi-square & df & Sig \\
\hline Pearson's correlation & 15.029 & 14 & .376 & 11.675 & 19 & .899 \\
\hline Deviance & 13.018 & 14 & .525 & 9.411 & 19 & .966 \\
\hline
\end{tabular}

\subsubsection{Pseudo R-square}

Table 25 reported Pseudo R-square results of the Cox and Snell, Nagelkerke and McFadden measures of effect size, which are commonly used in multiple regressions, approximately computed for multinomial logistic regression. So the higher Pseudo R-square that approached to 1 considered a better fit. In this case, Table 25 reported Negelkerke (.572) higher value than Cox and Snell (.427) and McFadden (.406) for profitability and sustainability of AIRCABS. Similarly, for stable deposit, Negelkerke (.780) higher value than McFadden (.648) and Cox and Snell (.562). The highest value of Pseudo R-square that showed by Negelkerke in Table 25 indicated the relationship between the predictor and predicted variables was strong. Furthermore, $40.6 \%$ up to $57.2 \%$ and $56.2 \%$ up to $78 \%$ of the variability explained by independent and dependent variables used in the model, respectively.

Table 25. Pseudo R-square

\begin{tabular}{|c|c|c|}
\hline \multicolumn{2}{|c|}{$\begin{array}{l}\text { Profitability and sustainability of } \\
\text { AIRCABS }\end{array}$} & \multirow{2}{*}{$\begin{array}{c}\text { Stable deposi } \\
.562\end{array}$} \\
\hline Cox and Snell & .427 & \\
\hline Nagelkerke & .572 & .780 \\
\hline McFadden & .406 & .648 \\
\hline
\end{tabular}

\subsubsection{Likelihood ratio tests}

It is a test for obtaining likelihood of observations with predictor variables considered in the model. Though similar statistical results of the null and full models in the model fitting information reported in Tables 22 and 23, the likelihood ratio tests in Tables 26 and 27 components of independent variables compared to the full model and each predicting independent variables significantly contributed to the full effect. According to the statistical result, the independent variables such as investor loan funding and discrete market deposit interest incentive together with their independent control variables significantly contributed to the effect of profitability and sustainability of AIRCABS and stable deposit mobilization, respectively. The Chi-square (8.912) in Table 26 and Chi-square (17.323) in Table 27 were significant at $p=0.003$ and $p=0.000$ respectively, which are less than the cut off $\mathrm{P}<0.05$. This indicated that the independent variables, such as Investor loan funding, Financial deepening, Per capita income, Growth domestic saving to GDP, Total private investment to bank deposit and Management efficiency, have created strong relationship with dependent variables, profitability and sustainability of AIRCABS as stated in Table 26. On the other hand, Table 27 displayed the independent variables such as dis-

Table 26. Likelihood ratio tests of profitability and sustainability of AIRCABS

\begin{tabular}{l|c|c|c|c|c|c}
\hline \multirow{2}{*}{ Effect } & \multicolumn{3}{c|}{ Model fitting criteria } & \multicolumn{3}{c}{ Likelihood ratio tests } \\
\cline { 2 - 7 } & $\begin{array}{c}\text { AIC of } \\
\text { reduced } \\
\text { model }\end{array}$ & $\begin{array}{c}\text { BIC of } \\
\text { reduced } \\
\text { model }\end{array}$ & $\begin{array}{c}-2 \\
\text { Log Likelihood } \\
\text { of reduced } \\
\text { model }\end{array}$ & $\begin{array}{c}\text { Chi- } \\
\text { square }\end{array}$ & df & Sig. \\
\hline $\begin{array}{l}\text { Intercept } \\
\begin{array}{l}\text { Investor loan funding*Financial } \\
\text { deepening * Per capita income * }\end{array} \\
\begin{array}{l}\text { Growth domestic saving to GDP * Total } \\
\text { private investment to bank deposit * } \\
\text { Management efficiency }\end{array}\end{array}$ & 23.799 & 24.572 & 21.799 & 8.781 & 1 & .003 \\
\hline
\end{tabular}

Note: the Chi-square statistic is the difference in -2 Log Likelihoods between the final model and a reduced model. The reduced model is formed by omitting an effect from the final model. The null hypothesis is that all parameters of that effect are 0. 
Table 27. Likelihood ratio tests of stable deposit

\begin{tabular}{|c|c|c|c|c|c|c|}
\hline \multirow[b]{2}{*}{ Effect } & \multicolumn{3}{|c|}{ Model fitting criteria } & \multicolumn{3}{|c|}{ Likelihood ratio tests } \\
\hline & $\begin{array}{c}\text { AIC of } \\
\text { reduced } \\
\text { model }\end{array}$ & $\begin{array}{l}\text { BIC of } \\
\text { reduced } \\
\text { model }\end{array}$ & $\begin{array}{l}-2 \text { Log } \\
\text { Likelihood } \\
\text { of reduced } \\
\text { model }\end{array}$ & Chi-square & df & Sig. \\
\hline Intercept & 19.890 & 20.935 & 17.890 & 8.479 & 1 & .004 \\
\hline $\begin{array}{l}\text { Special deposit ratio * Average deposit } \\
\text { interest rate } * \text { Discrete market deposit } \\
\text { interest incentive } * \text { Deposit interest } \\
\text { incentive rate }{ }^{*} \text { Efficiency of deposit } \\
\text { utilization ratio * Deposit interest payment } \\
\text { capacity }\end{array}$ & 28.734 & 29.778 & 26.734 & 17.323 & 1 & .000 \\
\hline
\end{tabular}

Note: the Chi-square statistic is the difference in -2 Log Likelihoods between the final model and a reduced model. The reduced model is formed by omitting an effect from the final model. The null hypothesis is that all parameters of that effect are 0 .

crete market deposit interest incentive, special deposit ratio, average deposit interest rate, deposit interest incentive rate, efficiency of deposit utilization ratio and deposit interest payment capacity have created strong relationship with dependent variable, stable deposit.

\subsubsection{Parameter estimates}

Tables 28 and 29 showed outcomes of multinomial logistic coefficient (B), standard error, Wald statistics, significant level, odd ratio (Exp (B)) and confidence interval of odd ratio.

The models estimated likelihood occurrence of sustainability and profitability of AIRCABS relative to likelihood of event occurrence no sustainability and profitability of AIRCABS in Table 28. Similarly, the likelihood occurrence of stable deposit mobilization estimated relative to likelihood occurrence of no stable deposit mobilization. So the model predicted the dependent variables using independent variable based on the magnitude of the parameter estimator, Coefficient, corresponding to the odd ratio.

As depicted in Table 28, a one-unit increment of each independent variable, investor loan funding together with its control variables such as financial deepening, Per capita income, growth domestic saving to GDP, total private investment to bank deposit and management efficiency increased the likelihood of predicting sustainability and profitability of AIRCABS by 111.242 times. Similarly, in Table 29, a one-unit increment of each independent variables, discrete market deposit interest incentive together with control variables such as deposit interest incentive rate, average deposit interest rate, special deposit, efficiency of deposit utilization, deposit interest payment capacity, increased

Table 28. Parameter estimates of profitability and sustainability of AIRCABS

\begin{tabular}{|c|c|c|c|c|c|c|c|c|c|}
\hline \multirow{2}{*}{\multicolumn{2}{|c|}{$\begin{array}{c}\text { Profitability and } \\
\text { sustainability of AIRCABS }\end{array}$}} & \multirow{2}{*}{ B } & \multirow{2}{*}{$\begin{array}{l}\text { Std. } \\
\text { error }\end{array}$} & \multirow{2}{*}{ Wald } & \multirow{2}{*}{ Df } & \multirow{2}{*}{ Sig. } & \multirow{2}{*}{$\operatorname{Exp}(B)$} & \multicolumn{2}{|c|}{$\begin{array}{l}95 \% \text { confidence interval } \\
\text { for } \operatorname{Exp}(B)\end{array}$} \\
\hline & & & & & & & & $\begin{array}{l}\text { Lower } \\
\text { bound }\end{array}$ & $\begin{array}{l}\text { Upper } \\
\text { bound }\end{array}$ \\
\hline \multirow[b]{2}{*}{ Roc } & Intercept & -5.048 & 2.274 & 4.928 & 1 & .026 & & & \\
\hline & $\begin{array}{l}\text { Investor loan funding } \\
\text { *Financial deepening } \\
\text { * Per capita income } \\
\text { * Growth domestic } \\
\text { saving to GDP * Total } \\
\text { private investment } \\
\text { to bank deposit * } \\
\text { Management efficiency }\end{array}$ & 111.242 & 48.651 & 5.228 & 1 & .022 & $2.051 \mathrm{E}+48$ & 7944764.170 & $5.293 E+89$ \\
\hline
\end{tabular}

Note: a. The reference category is: no profitability and sustainability of AIRCABS. 
Table 29. Parameter estimates of stable deposit

\begin{tabular}{|c|c|c|c|c|c|c|c|c|c|}
\hline \multirow{2}{*}{\multicolumn{2}{|c|}{ Stable deposit ${ }^{a}$}} & \multirow{2}{*}{ B } & \multirow{2}{*}{$\begin{array}{l}\text { Std. } \\
\text { error }\end{array}$} & \multirow{2}{*}{ Wald } & \multirow{2}{*}{ Df } & \multirow{2}{*}{ Sig. } & \multirow{2}{*}{$\operatorname{Exp}(B)$} & \multicolumn{2}{|c|}{$\begin{array}{l}95 \% \text { confidence } \\
\text { interval for } \operatorname{Exp}(B)\end{array}$} \\
\hline & & & & & & & & $\begin{array}{l}\text { Lower } \\
\text { bound }\end{array}$ & $\begin{array}{l}\text { Upper } \\
\text { bound }\end{array}$ \\
\hline & Intercept & -5.458 & 2.629 & 4.310 & 1 & .038 & & & \\
\hline $\begin{array}{l}\text { Stable } \\
\text { deposit }\end{array}$ & $\begin{array}{l}\text { Discrete market } \\
\text { deposit interest } \\
\text { incentive *Deposit } \\
\text { interest incentive } \\
\text { rate * Average } \\
\text { deposit interest rate } \\
\text { * Special deposit } \\
\text { ratio * Efficiency of } \\
\text { deposit utilization } \\
\text { ratio * Deposit } \\
\text { interest payment } \\
\text { capacity }\end{array}$ & 205.965 & 100.297 & 4.217 & 1 & .040 & $2.816 \mathrm{E}+89$ & 11927.027 & $6.647 \mathrm{E}+174$ \\
\hline
\end{tabular}

Note: a. The reference category is: no stable deposit.

the likelihood of predicting stable deposit mobilization by 205.965 times. In Tables 28 and 29, the odd ratios (Ext (B)) associated with each predictor increased and became greater than 1.0, which indicated that the likelihood of dependent variables strongly predicted by the independent variable. As depicted in Tables 28 and 29, as the coefficient was away from zero, the predictor variable had a high influence in predicting the logit which is being predicted and is the likelihood of the outcome variables. The Wald statistical test (5.228) which is significant at $\mathrm{P}=0.022$ in Table 28 and Wald statistics test (4.217) which is significant at $\mathrm{P}=.04$ in Table 29 increased the model fit to the data sufficiently. This assured that the individual predictors significantly contributed for the improvement of the model and the parameter is useful to the model (Bewick, Cheek, \& Ball, 2005; El-Habil, 2012).

The confidence interval (95\%), which is the interval where the true effect lied, was very supe- rior level though confidence interval that didn't include the null value (1) was greater than 1 and found to be significant. This implied that when exposed to risk, likelihood of having sustainability and profitability of AIRCABS in Table 28 and stable deposit in Table 29 more increased more than when an event was not exposed to risk. The odd ratio was very superior to 1 , which, in turn, indicated the likelihood of predictors that predicted the dependent variables was very superior. The combination of independent variables selected to predict the dependent variables was efficient. As evidenced by Table 22 up to Table 29 the dependent variables significantly created strong relationship with dependent variables. The models also predicted $87.5 \%$ and $90.5 \%$ correctly as indicated in Tables 30 and 31. So disregarding abnormally wide confidence interval the independent variables displayed in Tables 28 and 29 efficiently predicted the respective dependent variables.

Table 30. Classification

Profitability and sustainability of AIRCABS

\begin{tabular}{l|c|c|c}
\hline \multicolumn{1}{c}{ Observed } & \multicolumn{3}{c}{ Predicted } \\
\cline { 2 - 4 } & $\begin{array}{c}\text { Profitability and } \\
\text { sustainability of } \\
\text { AlRCABS }\end{array}$ & $\begin{array}{c}\text { No profitability and } \\
\text { sustainability of } \\
\text { AlRCABS }\end{array}$ & Percent correct \\
\hline $\begin{array}{l}\text { Profitability and sustainability of } \\
\text { AIRCABS }\end{array}$ & 6 & 1 & 8 \\
\hline $\begin{array}{l}\text { No profitability and sustainability of } \\
\text { AIRCABS }\end{array}$ & 1 & $85.7 \%$ \\
\hline Overall percentage & $43.8 \%$ & $86.3 \%$ & $87.5 \%$ \\
\hline
\end{tabular}




\subsubsection{Classification table}

Tables 30 and 31 showed the classification of how well our full model correctly predicted observed outcome of yes/no profitability and sustainability of AIRCABS and yes/no stable deposit in a bank, respectively. Therefore, the overall accuracy of the models predicted $87.5 \%$ and $90.5 \%$, as stated below for profitability and sustainability of AIRCABS and stable deposit, respectively.

Table 31. Percentage classification of stable deposit

\begin{tabular}{c|c:c|c}
\hline \multirow{2}{*}{ Observed } & \multicolumn{3}{|c}{ Predicted } \\
\cline { 2 - 4 } & $\begin{array}{c}\text { No } \\
\text { stable } \\
\text { deposit }\end{array}$ & $\begin{array}{c}\text { Stable } \\
\text { deposit }\end{array}$ & $\begin{array}{c}\text { Percent } \\
\text { correct }\end{array}$ \\
\hline No stable deposit & 13 & 1 & $92.9 \%$ \\
\hline stable deposit & 1 & 6 & $85.7 \%$ \\
\hline Overall percentage & $66.7 \%$ & $33.3 \%$ & $90.5 \%$ \\
\hline
\end{tabular}

\subsubsection{Comparing by chance accuracy with model accuracy rate}

The proportional by chance accuracy rate computed based on the proportion of yes/no profitability and sustainability of AIRCABS and yes/no stable deposit by squaring and summing proportion of each cases such that for profitability and sustain- ability of AIRCABS, $.438^{2}+.563^{2}=0.508813$, in Table 32 and for stable deposit, $.333^{2}+.667^{2}=0.555778$, in Table 33, respectively. The standard set to characterize multinomial logistic regression model as useful is to improve the overall percentage accuracy by more than $25 \%$ the proportion by chance accuracy. So, according to the proportion by chance accuracy criteria, the percentage of by chance accuracy of the model was $63.60 \%$ $(1.25 \mathrm{x} .508813=63.60 \%)$ for profitability and sustainability of AIRCABS, though the model accuracy rate was $87.5 \%$ as stated in Table 30 , whereas for stable deposit the proportional by chance accuracy calculated as $69.47 \%(1.25 \times 0.555778=0.6947225)$, though the model accuracy rate was $90.5 \%$ as stated in Table 31. The model accuracy rate over by chance accuracy implied that the employed multinomial logistic regression model was useful.

The result of multinomial logistic regression to predict profitability and sustainability of AIRCABS using predictors variables such as Investor loan funding together with its control variables, financial deepening, Per capita income, growth domestic saving to GDP, total private investment to bank deposit and management efficiency, was significant. So the alternative hypothesis stated that investor loan funding has positive effect on sustainability and profitability of AIRCABS was accepted

Table 32. Case processing summary

\begin{tabular}{|c|c|c|c|}
\hline & Criteria & $\mathbf{N}$ & $\begin{array}{c}\text { Marginal } \\
\text { Percentage }\end{array}$ \\
\hline \multirow{2}{*}{$\begin{array}{l}\text { Profitability and sustainability of } \\
\text { AIRCABS }\end{array}$} & Profitability and sustainability of AIRCABS & 7 & $43.8 \%$ \\
\hline & No profitability and sustainability of AIRCABS & 9 & $56.3 \%$ \\
\hline \multicolumn{2}{|r|}{ (1) } & 16 & $100.0 \%$ \\
\hline \multicolumn{2}{|l|}{ Missing } & 5 & \\
\hline \multicolumn{2}{|l|}{ Total } & 21 & \\
\hline \multicolumn{2}{|l|}{ Subpopulation } & $16^{\mathrm{a}}$ & \\
\hline
\end{tabular}

Note: a. The dependent variable has only one value observed in 16 (100.0\%) subpopulations.

Table 33. Case processing summary

\begin{tabular}{|c|c|c|c|}
\hline & Criteria & $\mathbf{N}$ & $\begin{array}{c}\text { Marginal } \\
\text { percentage }\end{array}$ \\
\hline \multirow{2}{*}{ Stable deposit } & No stable deposit & 7 & $33.3 \%$ \\
\hline & Stable deposit & 14 & $66.7 \%$ \\
\hline \multicolumn{2}{|l|}{ Valid } & 21 & $100.0 \%$ \\
\hline \multicolumn{2}{|l|}{ Missing } & 0 & \\
\hline \multicolumn{2}{|l|}{ Total } & 21 & \\
\hline \multicolumn{2}{|l|}{ Subpopulation } & $21 \mathrm{a}$ & \\
\hline
\end{tabular}

Note: a. The dependent variable has only one value observed in $21(100.0 \%)$ subpopulations. 
by rejecting the null hypothesis that there is no difference between a model with and without independent predicting variables to predict the dependent variables.

Similarly, the result of multinomial regression to predict stable deposit using predictor variables such as discrete market deposit interest incentive together with its control variables such as deposit interest incentive rate, average deposit interest rate, special deposit ratio, efficiency of deposit utilization ratio and deposit interest payment capacity was significant. So the alternative hypothesis stated that discrete market deposit interest incentive has a positive impact on stable deposit mobilization in case a bank finance an entrepreneur which later shift to agent position when depositor needs to be an investor was accepted by rejecting the null hypothesis that there is no difference between models with and without independent predicting variables to predict the dependent variables.

\subsubsection{Individual perception on investor loan funding and discrete market deposit interest incentive}

In quantitative measurement, the coefficient of variation calculated as standard error to its parameter estimator value. In Tables 28 and 29, the coefficient of variation of investor loan funding predicting variables was calculated as .44 at significant level $(\mathrm{P}=.022)$, whereas the coefficient of variation for discrete market deposit interest rate incentive calculated as .49 at a significant level $(\mathrm{P}=.040)$, where the standard level of significance for this research study is $\mathrm{P}<.05$. The coefficient of variation calculated above helped to assimilate the perception of individuals' survey participants with the real practice depicted based on financial statements.
To investigate the degree of agreement and disagreement, the cut off point for coefficient of variation $(\mathrm{CV})$ to interpret survey instrument of investor loan funding (ILF) and discrete market deposit interest incentives considered below .50, and above this ceiling level, data were interpreted with caution. Accordingly, all survey participants strongly agreed with the point of survey questions except survey questions ILF-Q3 (CV .55) and ILFQ4(CV .85), which were a little bit far from central tendency.

Generally, among all survey respondents, 79\% of individual participants of investor loan funding survey questionnaires agreed, whereas $88 \%$ of individual participants of discrete market deposit interest incentive questionnaires agreed with majority of questions in survey instruments.

In quantitative analysis, significant result showed that investor loan funding predicted and created strong relationships with sustainability and profitability of AIRCABS. On the other hand, discrete market deposit interest incentives predicted and have a strong relationship with stable deposit mobilization. The coefficient of variation calculated based on the quantitative data to show investor loan funding was a true predictor of sustainability and profitability of AIRCABS and discrete market deposit interest rate incentive was a true predictor of stable deposit variables. The coefficient of variation calculated based on perception of individual survey participant showed almost below the coefficient of variation calculated in quantitative measurement. This implied that the individual perception to the point of survey question and the result of quantitative measurement were found to be concurrent. Therefore, alternative hypotheses ( $\mathrm{H} 1$ and $\mathrm{H} 2)$ were accepted.

\section{CONCLUSION}

In conventional banking activities, banks either retain or transfer credit and liquidity risk to other financial institutions which later have the same impact on the overall industry. Since bank sells customer deposit having considered as its own asset in its balance sheet, in most instances, banks are exposed to toxic asset, non-performing asset or contagion and short of liquidity problems. Once the bank is exposed to credit risk, it is indirectly affected by hidden financial cost, which the bank was paying interest to depositors on uncollectible loan already disbursed from the depositors' accounts. 
To increase sustainability, profitability and stable fund of AIRCABS by transferring credit risk and liquidity crunch to investors and entrepreneurs, an interest rate commission agent banking system was developed. This can be done by empowering money depositor to exercise their full right for the use of their money to get reasonable credit price rather than offering unreasonable deposit interest rate that forced them to join the informal market.

An interest rate commission agent banking system (AIRCABS) transfers risk to investors and entrepreneurs through its lending strategies, 360 degrees, 180 degrees and 90 degree (Tessema \& Kruger, 2016).

The reliability and viability of an interest rate commission agent banking system was investigated based on the significant test result of individual survey participants' perception and financial data.

Before getting into analysis of individual perceptions, the validity and reliability of survey questionnaires were tested using Cronbanch's alpha, Kuder-Richardson, descriptive statistics and factor analysis and significant results weres found. The individual survey participants' perception supported the empirical analysis result, which was based on financial statements of all commercial banks in Ethiopia.

Since an interest rate commission agent banking system administers the fund of investor loan funding to entrepreneur by transferring credit and liquidity risks to investor and entrepreneurs, credit risk and liquidity crunch had no effect on the sustainability and profitability of AIRCABS. This idea was supported by testing the first hypothesis (H0) independent and dependent variables applying canonical correlation. Accordingly, the impact of credit risk and liquidity crunch (deposit run, credit crunch, liquidity risk, non-performing asset and credit risk) on AIRCABS (non-interest income, bank efficiency, return on asset, return on equity and capital adequacy) was investigated and no relationship was found.

The main activity of traditional banking was maximizing the net interest margin, which is the income from buying and selling of fund, having borne credit risks and liquidity crunch. However, the main target of AIRCABS is to maximize the agreed interest rate commission from investor loan funding administration and project selection fee. Since AIRCABS did not hold customer fund as an asset on its balance sheet, no financial expense thinkable. So AIRCABS enables the agent bank to collect loan interest rate commission and fee by transferring liquidity and credit risk to investors and entrepreneurs. This notion was supported by testing the research hypothesis ( $\mathrm{H1}$ ) to investigate the relationship between dependent variables, investor loan funding with its control variables such as financial deepening, per capita income, growth domestic saving to GDP, total private investment to bank deposit and management efficiency, and dependent variables, profitability and sustainability of AIRCABS, using multinomial logistic regression. The statistical result showed that investor loan funding together with its control variables predicted sustainability and profitability of AIRCABS. This implied that as the agent bank's efficiency in administering investor loan increases, the agent bank's sustainability and profitability increases. As a result, investment on innovative entrepreneurs' project increases, this, in turn, increases import substitution products and the country's GDP in general.

As the competition among banks in service excellence increases the likelihood of deposit stability at the origin, depository bank decreases. Money deposit of customers is the lifeblood of the traditional banks to maintain its sustainability and profitability in the market, in particular, and financial stability in general. In most instances, retail deposit, deposited by major society, is more stable than wholesale deposit, deposit by few society, in connection with the benefit of deposit interest rate. As interest rate increases, the interest of small money depositors' increases and thereby stable deposit will be established. So applying discrete market deposit interest rate incentive on the marginal increment of money deposited enables to have more deposit clientele which, in turn, enhances stability of deposit. This notion was supported by testing the research hypothesis $(\mathrm{H} 2)$ by investigating the relationship between independent and dependent variables using multinomial logistic regression. The statistical result showed that there 
was a strong relationship between independent variables, discrete market deposit interest incentive with its control variables such as a special deposit ratio, average deposit interest rate, deposit interest incentive rate, efficiency of deposit utilization ratio and deposit interest payment capacity, and the dependent variable, stable deposit. This implied that a fraction of the unit increment on discrete market deposit interest rate incentive enables the bank to have a wide margin of deposit from time to time, which, in turn, significantly increases the stability of deposit.

In general, an interest rate commission agent banking system was tested using different statistical tools to find internal and external resistance of the model at a buffer stage where the market and economic shock exhibited. Since the statistical test result found was significant on cause and effect relationship in testing the hypotheses, this brought into a conclusion that an interest rate commission agent banking model is viable, as well as reliable.

\section{REFERENCES}

1. Adrian, T. (2015). Discussion of Systematic Risk and the Solvency-Liquidity Nexus of Banks. International Journal of Central Banking, 11(3), 229-240. Retrieved from www.ijcb.org

2. Allen, F., \& Carletti, E. (2006). Credit Risk Transfer and Contagion. Journal of Monetary Economics, 53, 89-111. http:// dx.doi.org/10.1016/j.jmoneco.2005.10.004

3. Alpert, Mark I., \& Robert A. Peterson. (1972). On the Interpretation of Canonical Analysis. Journal of Marketing Research, 9, May, 187. http://dx.doi. $\operatorname{org} / 10.2307 / 3149953$

4. Baicu, C. G., \& State, O. (2012). Banking Model under the Impact of the Post-Crisis Organizational Changes Aptto Confer Sustainable Financial Stability-Romanian Experience. Amfiteatru Economic, XIV(32), 436-450. Retrieved from http://econpapers.repec.org/article/ aesamfeco/v_3a14_3ay_3a2012_3ai_ 3a32_3ap_3a436-450.htm

5. Bayaga, A. (2010). Multinomial Logistic regression: Usage and application in risk analysis. JAQM, 5(2), 288-297. Retrieved from www. jaqm.ro

6. Bewick, V., Cheek, L., \& Ball, J. (2005). Statistics review 14: Logistic regression. Critical Care (London, England), 9(1), 112-118. http:// dx.doi.org/10.1186/cc3045

7. Blommestein, H. J., Keskinler, A., \& Lucas, C. (2011). Outlook for the Securitization Market, OECD Journal Financial Market Trends, 1, 1-18. Retrieved from www.oecd.org

8. Brown, C. C. (1982). On a goodness of fit test for logistic model based on score statistics. Communication in statistics: Theory and Method, 11, 1087-1105. http://dx.doi. org/10.1080/03610928208828295

9. Bruno, B., \& Bedendo, M. (2013). Credit risk transfer in U.S. commercial banks: What changed during the 2007-2009 Crisis? Journal of Banking Finance, 36, 3260-3273. Retrieved from www.elsevier.com/ locate/jbf

10. Castro, F. G., Kellison, J. G, Boyd, S. J., \& Kopak, A. (2010). A Methodology for Conducting Integrative Mixed Methods Research and Data Analyses. Journal of Mixed Methods Research, 4(4), 342-360. http://dx.doi. org/10.1177/1558689810382916

11. Chronbach, L. J. (1951). Coefficient Alpha and The Internal Structure Of Tests. Psychometrical, 16(3), 297-334. http://dx.doi.org/10.1007/ BF02310555

12. Cohen J. (1992). A power primer: Quantitative methods in psychology. Psychol. Bull., 112(1), 155-159. http://dx.doi. org/10.1037/0033-2909.112.1.155

13. Cortina, J. (1993). What is coefficient alpha: an examination of theory and applications. Journal of applied psychology, 78, 98-104. http://dx.doi.org/10.1037/00219010.78.1.98

14. Creswell, J. W. (2003). Research design: Quantitative, Qualitative, and Mixed methods Approaches ( $2^{\text {nded. }}$.). Sage Publication, London, 4-26. Retrieved from https:// us.sagepub.com

15. Curto, J. D., \& Pinto, J. C. (2009). The coefficient of variation asymptotic distribution in the case of non-iid random variables. Journal of Applied Statistics, 36(1), 21-32. http://dx.doi. org/10.1080/02664760802382491

16. Engel, R. J., \& Schutt, R. K. (2013). The Practice of Research in Social Work (3rd ed.). Sage Publication Inc., 97-104. Retrieved from https:// us.sagepub.com

17. Field, A. (2009). Discovering Statistics using SPSS. Sage: London. Retrieved from https://us.sagepub. com

18. Gogoncea, R., \& Paun, Id. (2013). Pros and cons of using derivatives. Theoretical and Applied Economics, XX(9(589)), 87-102. Retrieved from http://www.ectap.ro/

19. Green S., Lissitz R., Mulaik S. (1977). Limitations of coefficient alpha as an index of test unidimensionlity. Educational Psychological Measurement, 37, 827-38. http://dx.doi. org/10.1177/001316447703700403

20. Hair, J. F., Anderson, R. E., Tatham, R. L., \& Black, W. C. (1998). Multivariate Data Analysis (5th edition). Englewood Cliffs, NJ: Prentice Hall. 
21. Hosmer, D. W., \& Lemeshow, S. (2000). Applied Logistic Regression (2nd ed.). John Wiley and Sons Inc.NewYork. http://dx.doi. org/10.1002/0471722146

22. Kaiser, H. F. (1974). An index of Factorial Simplicity. Psychometrika, 23, 187-200. Retrieved from http://www. springer.com/psychology/journal/11336/PS2

23. Kelley, K. (2007). Sample size planning for the coefficient of variation from the accuracy in parameter estimation approach. Behavior Research Methods, 39(4), 755-766. http://dx.doi. org/10.3758/BF03192966

24. Lambert, Z., \& Durand, R. (1975). Some Precautions in Using Canonical Analysis. Journal of Marketing Research, 12, November, 468-475. http://dx.doi. org $/ 10.2307 / 3151100$

25. Liu, J., Drane W., Liu X, Wu T. (2009). Examination of the relationships between environmental exposures to volatile organic compounds and biochemical liver tests: application of canonical correlation analysis. Environmental research, 109, 193199. http://dx.doi.org/10.1016/j. envres.2008.11.002

26. Lovie, P. (2005). Coefficient of Variation, Encyclopedia of Statistics in Behavioral Science. John Wiley \& Sons, Ltd. http:// dx.doi.org/10.1002/0470013192. bsa107

27. El-Habil, M. (2012). An application of Multinomial Logistic regression Model. Pakistan journal of statistics and operation research, VIII(2), 271291. http://dx.doi.org/10.18187/ pjsor.v8i2.234

28. Mandel, B. H., Morgan, D., \& Wei, C. (2012). The Role of Bank Credit Enhancements in Securitization. FRBNY Economic Policy Review, 18(2), 35-46. Retrieved from https://www.questia.com/library/ journal/1G1-301180662

29. Memmel, M., Sachs, A., \& Stein, I. (2012). Contagion In The Interbank Market With Stochastic Loss Given Default. International journal Of Central Banking, 8(3), 177-206. Retrieved from http:// www.ijcb.org/journal/ijcb12q3a5. htm

30. Moise, N. M., \& Ilie, E. (2012). Financial Crisis Impact on Bank Deposits Guarantee. International Journal of Academic Research In Economics and Management Sciences, 1(1), 39-45. Retrieved from http://hrmars.com/index. php/journals/archive_detail/IJAREMS/9

31. Prentice, R. L. (1976). A Generalization of the probit and logit methods for dose response curves. Biometrics, 32, 761-768. http://dx.doi.org/10.2307/2529262

32. Pryseley, A., Mintiens, K., Knapen K., Stede, Y. V. D., \& Molenberghs, G. (2010). Estimating Precision, Repeatability, and Reproducibility From Gaussian and Non-Gaussian Data: A Mixed Models Approach. Journal of applied statistics, 37(10), 1729-1747. http://dx.doi. org/10.1080/02664760903150706

33. Rattray, J., \& Jones, M. C. (2007). Essential elements of questionnaire design and development. Journal of Clinical Nursing, 16, 234-243. http:// dx.doi.org/10.1111/j.13652702.2006.01573.x

34. Salvucci, S., Walter, E., Conley, V., Fink, S., \& Saba, M. (1997). Measurement Error Studies at the national center for Education Statistics (NCES). Washington D.C: U.S. Department of Education, 115120. Retrieved from https://eric. ed.gov/?id=ED410313

35. Schouten, B., Calinescu, M., \& luiten, A. (2013). Optimizing Quality of Response through Adaptive Survey Design. Survey methodology, 39(1), 29-58. Retrieved from www.statcan.gc.ca

36. Sherry, A., \& Henson, R. K. (2005). Conducting and interpreting canonical correlation analysis in personality research: A user-friendly primer. Journal of Personality Assessment, 84, 3748. http://dx.doi.org/10.1207/ s15327752jpa8401_09
37. Simon-oak, O. O., \& Jolaosho, O. M. (2013). Real Interest rate and Savings Mobilization in Nigeria. International Journal of Development and Economic Sustainability, 1(2), 28-40. Retrieved from http://www.eajournals.org

38. Stewart, D., \& Love, W. (1968). A General Canonical Correlation Index. Psychological Bulletin, 70(3), 160-163. http://dx.doi. org/10.1037/h0026143

39. Tate, R. (2003). A comparison of selected empirical methods for assessing the structure of responses to test items. Applied Psychological Measurement, 27, 159-203. http://dx.doi.org/10.1177 /0146621603027003001

40. Tessema, A. T., \& Kruger, J. W. (2016). A Methodology To Test Viability of An Interest Rate Commission Agent Banking System (AIRCABS). International Journal Of Business Research, 16(5), 21-40. http://dx.doi.org/10.18374/ IJBR-16-5.2

41. Thompson, B. (1991). A primer on the logic and use of canonical correlation Analysis. Measurement and Evaluation in Counselling and Development, 24, 80-95. Retrieved from https://eric. ed.gov/?id=EJ434121

42. Wagner, W., \& Marsh, I. W. (2006). Credit Risk transfer and Financial sector Stability. Journal of Financial Stability, 2, 173193. https://doi.org/10.1016/j. jfs.2005.11.001

43. Young, T., McCord, L., \& Crawford, P. J. (2010). Credit Default Swaps: The Good, The bad and The Ugly. Journal of Business and Economic Research, 8(4), 2935. Retrieved from https://www. cluteinstitute.com/ojs/index.php/ JBER/article/view/700/686

44. Zuckerman, A. M. (2011). Securitization Reform: A Coasean Cost Analysis. Harvard Business Law Review, 1(1), 303-317. Retrieved from www.hblr.org/wpcontent/uploads/2014/09/Zuckerman-Securitization_Reform 
Table 1. Indicators of credit risk and liquidity crunch measures

\begin{tabular}{|c|c|c|c|c|c|c|}
\hline No. & Indicator & 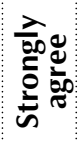 & $\underset{\frac{1}{2}}{\frac{8}{\alpha}}$ & $\begin{array}{l}\overline{\widetilde{T}} \\
\overline{\underline{J}} \\
\mathbf{Z}\end{array}$ & 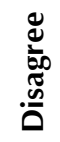 &  \\
\hline 1 & Decrement of bank's loan growth and capital is a sign of liquidity crunch & \multirow{16}{*}{5} & \multirow{16}{*}{4} & \multirow{16}{*}{3} & \multirow{16}{*}{2} & \multirow{16}{*}{1} \\
\hline 2 & $\begin{array}{l}\text { Bank lending practices that lead borrower more vulnerable to abusive practice enhance } \\
\text { liquidity crunch }\end{array}$ & & & & & \\
\hline 3 & The bank that involved in high level of interest income exposed to the liquidity crunch & & & & & \\
\hline 4 & The misjudgment of bank strategies increases the bank liquidity risk & & & & & \\
\hline 5 & Bank failures sourced from effect of deposit run & & & & & \\
\hline 6 & $\begin{array}{l}\text { High illiquid asset that is unaccepted for common valuation in the market is the source } \\
\text { liquidity risk }\end{array}$ & & & & & \\
\hline 7 & Instability of depositors led the bank to liquidity risk & & & & & \\
\hline 8 & Diversifying loan funded by bank out of intended purpose led the borrower to default & & & & & \\
\hline 9 & Funding loan from bank to entrepreneur as own asset increases the bank's credit risk & & & & & \\
\hline 10 & Credit operation weakness of borrower leads the loan to default & & & & & \\
\hline 11 & Loan sanctioned by corruption leads the borrower to default & & & & & \\
\hline 12 & $\begin{array}{l}\text { Lack of good credit assessment and follow up by bank leads to increase of nonperforming } \\
\text { asset }\end{array}$ & & & & & \\
\hline 13 & Borrowers default for lack of management support from credit institutions & & & & & \\
\hline 14 & Buying and selling of money exposes the bank to credit risk & & & & & \\
\hline 15 & $\begin{array}{l}\text { Decline of commodity prices for exporters who used bank loan facility can result in } \\
\text { higher nonperforming loans (NPLs) }\end{array}$ & & & & & \\
\hline 16 & As capital adequacy increases, credit risk of the bank decreases & & & & & \\
\hline
\end{tabular}

Table 2. Indicators of investor loan funding measures

\begin{tabular}{|c|c|c|c|}
\hline No. & Indicator &  &  \\
\hline 1 & Investor loan funding increases the agent bank's profitability in broad sample base & \multirow{6}{*}{1} & \multirow{6}{*}{0} \\
\hline 2 & Investor's loan funding enhances the bank liquidity and efficiency & & \\
\hline 3 & Investor loan funding can enhance the bank's loan administrative efficiency and capacity & & \\
\hline 4 & $\begin{array}{l}\text { Funding loan by investor to entrepreneur through an interest rate commission agent banking } \\
\text { system eliminates the bank exposure to credit risk and liquidity crunch }\end{array}$ & & \\
\hline 5 & $\begin{array}{l}\text { As the supply of loan funding by investor to entrepreneur's increases through an interest rate } \\
\text { commission agent banking system, investment in a country enhances and thereby increases the } \\
\text { country's GDP }\end{array}$ & & \\
\hline 6 & Benefiting credit price to investor loan funding enhances the agent bank interest rate commission & & \\
\hline
\end{tabular}


Table 3. Indicators of discrete market deposit interest incentive measures

\begin{tabular}{|c|c|c|c|}
\hline No. & Indicator & 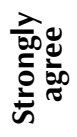 & 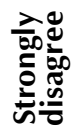 \\
\hline 1 & The increase of deposit interest rate increases the demand of the depositor & \multirow{5}{*}{1} & \multirow{5}{*}{0} \\
\hline 2 & $\begin{array}{l}\text { Applying discrete market interest rate incentive for those deposit's volumes increases the } \\
\text { demand of depositor to keep their deposit stable }\end{array}$ & & \\
\hline 3 & $\begin{array}{l}\text { Applying various level deposit interest rate incentives for depositors enable the bank to get a } \\
\text { more stable deposit }\end{array}$ & & \\
\hline 4 & $\begin{array}{l}\text { Allowing depositor to participate in bank's investment by paying proportionate credit price for } \\
\text { their partial or full fund enable the bank to have a more stable fund }\end{array}$ & & \\
\hline 5 & $\begin{array}{l}\text { Interest incentive on deposit in terms of incentive in kind enables the bank to hold more } \\
\text { clientele }\end{array}$ & & \\
\hline
\end{tabular}

Table 4. Indicators of AIRCABS measures

\begin{tabular}{|c|c|c|c|c|c|c|}
\hline No. & Indicator & 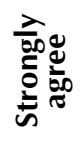 & 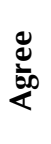 & $\overline{\text { Z }}$ & 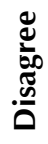 & 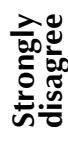 \\
\hline 1 & $\begin{array}{l}\text { The bank's buying and selling of fund deprived the depositor's to get } \\
\text { credit price }\end{array}$ & \multirow{9}{*}{5} & \multirow{9}{*}{4} & \multirow{9}{*}{3} & \multirow{9}{*}{2} & \multirow{9}{*}{1} \\
\hline 2 & $\begin{array}{l}\text { As deposit and credit interest rate approach equilibrium point the } \\
\text { bank shall work as an interest rate commission agent for investor loan } \\
\text { funding to entrepreneur to enhance its sustainability in market }\end{array}$ & & & & & \\
\hline 3 & $\begin{array}{l}\text { Providing alternative investment opportunity to fund provider by } \\
\text { AIRCABS enable to enhance stable fund in the bank }\end{array}$ & & & & & \\
\hline 4 & $\begin{array}{l}\text { Providing high deposit interest rate and credit price by AIRCABS } \\
\text { enable the bank to attract funds from the unbanked and banked } \\
\text { society }\end{array}$ & & & & & \\
\hline 5 & $\begin{array}{l}\text { Administering investor loan funding through AIRCABS enable to } \\
\text { eradicate liquidity crunch }\end{array}$ & & & & & \\
\hline 6 & $\begin{array}{l}\text { Bank can transfer credit risk using AIRCABS to the fund holder and } \\
\text { investor to increase its profitability and sustainability }\end{array}$ & & & & & \\
\hline 7 & $\begin{array}{l}\text { AIRCABS enables the fund owner to search potential borrowers with } \\
\text { or without collateral in the market to provide a credit facility using the } \\
\text { bank as an agent }\end{array}$ & & & & & \\
\hline 8 & $\begin{array}{l}\text { The right of the investor and depositors to get their fund return will be } \\
\text { safely kept by the bank using AIRCABS }\end{array}$ & & & & & \\
\hline 9 & $\begin{array}{l}\text { Under AIRCABS the bank's profit will be simply maximized without } \\
\text { financial expense }\end{array}$ & & & & & \\
\hline
\end{tabular}


APPENDIX 2

Table 5. Measures of liquidity crunch ratio

\begin{tabular}{c|c}
\hline Indicator & \multicolumn{1}{c}{ Interpretation } \\
\hline Deposit run $\left(\frac{\Delta D}{T D}\right)$ & $\begin{array}{l}\text { This ratio measures the deposit run on bank as a percentage of change in } \\
\text { deposit to total deposit. As the percentage of change in deposit decline, } \\
\text { there is a run on bank by depositors. }\end{array}$ \\
Credit crunch $\left(\frac{\Delta L}{T L}\right)$ & $\begin{array}{l}\text { This ratio measures the decline of supply of loan at macro level as } \\
\text { percentage of decline of change in loan and advance to total outstanding } \\
\text { loan. }\end{array}$ \\
Liquidity risk exposure $\left(\frac{L A}{T D}\right)$ & $\begin{array}{l}\text { This ratio measures the liquidity risk of the bank as percentage of liquid } \\
\text { assets to the sum total of customers deposit and bank's short term } \\
\text { borrowing. }\end{array}$ \\
\hline
\end{tabular}

Table 6. Measures of credit risk ratio

\begin{tabular}{c|c}
\hline Indicator & \multicolumn{1}{c}{ Interpretation } \\
\hline Non-performing asset ratio $\left(\frac{N P L S}{T L}\right)$ & $\begin{array}{l}\text { This ratio measures the level of non-performing asset to total loan } \\
\text { portfolio. }\end{array}$ \\
Credit risk $\left(\frac{L L P}{T L}\right)$ & $\begin{array}{l}\text { This is a measure of loan loss provision to total loan. As the ratio increases, } \\
\text { the bank is exposed to credit risk. }\end{array}$ \\
Commodity price shock ratio $\left(\frac{\Delta p}{p_{0}}\right)$ & $\begin{array}{l}\text { This is a measure of change in the current price as percentage of the last } \\
\text { price }\end{array}$ \\
\hline
\end{tabular}

Table 7. Measures of investor loan funding ratio

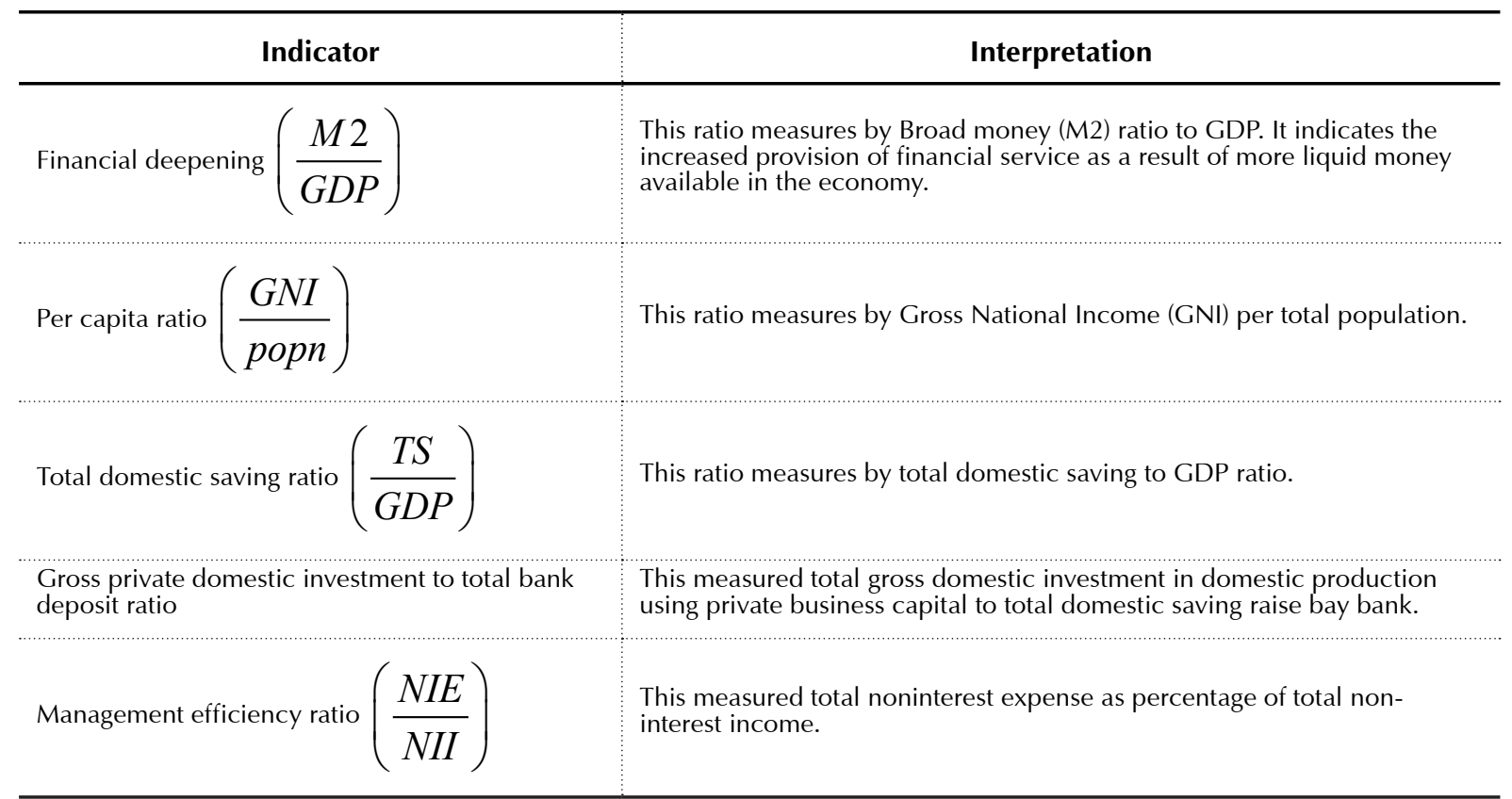


Table 8. Measures of discrete market deposit interest incentive ratio

\begin{tabular}{l|l}
\multicolumn{1}{c|}{ Indicator } & \multicolumn{1}{c}{ Interpretation } \\
\hline Deposit rate $(A V D R)$ & $\begin{array}{l}\text { This ratio measured commercial bank average deposit } \\
\text { interest rate. As the deposit rate increases the bank } \\
\text { deposit mobilization increases. }\end{array}$ \\
\hdashline Special deposit ratio $(S P D R)$ & $\begin{array}{l}\text { This ratio measured money deposited in the bank for the } \\
\text { specific purpose of the customer benefit and will not be } \\
\text { withdrawn at any time by the customer as a ratio of total } \\
\text { deposit. }\end{array}$ \\
\hline Deposit interest incentive rate $(D I I R)$ & $\begin{array}{l}\text { This measured the change in growth of deposit interest } \\
\text { rate as a percentage of total deposit interest rate. }\end{array}$ \\
\hline Efficiency of deposit utilization ratio $(E D U R)$ & $\begin{array}{l}\text { This measured total interest expense as percentage of } \\
\text { total loan interest rate. }\end{array}$ \\
\hline Deposit interest incentive payment capacity ratio $(D I P C)$ & $\begin{array}{l}\text { This ratio measures deposit interest expense as } \\
\text { percentage of total capital. }\end{array}$ \\
\hline
\end{tabular}

Table 9. Measure of AICABS ratio

\begin{tabular}{|c|c|}
\hline Indicator & Interpretation \\
\hline Non-interest income growth rate ( NIN ) & $\begin{array}{l}\text { This ratio measured the growth of non-interest income to } \\
\text { total income. }\end{array}$ \\
\hline Bank's efficiency ratio ( $E F R$ ) & $\begin{array}{l}\text { This ratio measured a total of non-interest income as } \\
\text { percentage of non-interest expense. }\end{array}$ \\
\hline Return on asset $(R O A)$ & $\begin{array}{l}\text { This ratio measured the gross interest rate commission as } \\
\text { a percentage of total fixed assets. }\end{array}$ \\
\hline Return on equity ( $R O E$ ) & $\begin{array}{l}\text { This ratio measured net income excluding interest } \\
\text { expense as percentage of the equity of the bank. }\end{array}$ \\
\hline Capital adequacy ratio ( $C A$ ) & $\begin{array}{l}\text { This ratio measures the bank's capital as percentage of } \\
\text { administrative expenses. }\end{array}$ \\
\hline
\end{tabular}

